Atmos. Chem. Phys., 13, 4877-4893, 2013

www.atmos-chem-phys.net/13/4877/2013/

doi:10.5194/acp-13-4877-2013

(c) Author(s) 2013. CC Attribution 3.0 License.

\title{
Overview of aerosol properties associated with air masses sampled by the ATR-42 during the EUCAARI campaign (2008)
}

\author{
S. Crumeyrolle ${ }^{1,2}$, A. Schwarzenboeck ${ }^{1}$, J. C. Roger $^{1}$, K. Sellegri ${ }^{1}$, J. F. Burkhart ${ }^{3}$, A. Stohl ${ }^{3}$, L. Gomes ${ }^{4}$, \\ B. Quennehen ${ }^{1,5}$, G. Roberts ${ }^{4}$, R. Weigel ${ }^{1,6}$, P. Villani ${ }^{1,7}$, J. M. Pichon ${ }^{1}$, T. Bourrianne ${ }^{4}$, and P. Laj ${ }^{1,7}$ \\ ${ }^{1}$ Laboratoire de Météorologie Physique, CNRS, Université Blaise Pascal, UMR6016, Clermont-Ferrand, France \\ ${ }^{2}$ NASA Langley Research Center, Hampton, VA 23666, USA \\ ${ }^{3}$ Norwegian Institute for Air Research, Kjeller, Norway \\ ${ }^{4}$ Centre National de Recherches Météorologiques, Météo-France, Toulouse, France \\ ${ }^{5}$ UPMC Univ. Paris 06, Université Versailles St-Quentin, CNRS/INSU, LATMOS-IPSL, UMR8190, Paris, France \\ ${ }^{6}$ Institute for Physics of the Atmosphere, Johannes Gutenberg University, Mainz, Germany \\ ${ }^{7}$ Laboratoire de Glaciologie et Géophysique de l'Environnement, Université de Grenoble, CNRS, Grenoble, France
}

Correspondence to: S. Crumeyrolle (suzanne.crumeyrolle@gmail.com)

Received: 20 March 2012 - Published in Atmos. Chem. Phys. Discuss.: 12 April 2012

Revised: 15 April 2013 - Accepted: 16 April 2013 - Published: 14 May 2013

\begin{abstract}
Within the frame of the European Aerosol Cloud Climate and Air Quality Interactions (EUCAARI) project, the Météo-France aircraft ATR-42 performed 22 research flights over central Europe and the North Sea during the intensive observation period in May 2008. For the campaign, the ATR-42 was equipped to study the aerosol physical, chemical, hygroscopic and optical properties, as well as cloud microphysics. For the 22 research flights, retroplume analyses along the flight tracks were performed with FLEXPART in order to classify air masses into five sectors of origin, allowing for a qualitative evaluation of emission influence on the respective air parcel.

This study shows that the extensive aerosol parameters (aerosol mass and number concentrations) show vertical decreasing gradients and in some air masses maximum mass concentrations (mainly organics) in an intermediate layer $(1-3 \mathrm{~km})$. The observed mass concentrations (in the boundary layer (BL): between 10 and $30 \mu \mathrm{g} \mathrm{m}^{-3}$; lower free troposphere (LFT): 0.8 and $14 \mu \mathrm{g} \mathrm{m}^{-3}$ ) are high especially in comparison with the 2015 European norms for $\mathrm{PM}_{2.5}$ $\left(25 \mu \mathrm{g} \mathrm{m}^{-3}\right)$ and with previous airborne studies performed over England (Morgan et al., 2009; McMeeking et al., 2012).

Particle number size distributions show a larger fraction of particles in the accumulation size range in the LFT compared to BL. The chemical composition of submicron aerosol particles is dominated by organics in the $\mathrm{BL}$, while ammonium
\end{abstract}

sulphate dominates the submicron aerosols in the LFT, especially in the aerosol particles originated from north-eastern Europe $(\sim 80 \%)$, also experiencing nucleation events along the transport. As a consequence, first the particle $\mathrm{CCN}$ acting ability, shown by the $\mathrm{CCN} / \mathrm{CN}$ ratio, and second the average values of the scattering cross sections of optically active particles (i.e. scattering coefficient divided by the optical active particle concentration) are increased in the LFT compared to BL.

\section{Introduction}

Aerosols are known to have significant impact on the regional and global climate via interaction with the solar and terrestrial radiation, thereby modifying the planetary albedo and the outgoing longwave radiation (IPCC, 2007). Aerosols originate either from natural sources or emission by anthropogenic activities (e.g. mineral dust, sea salt, black carbon, sulfate, biomass burning smoke, biogenic aerosols). During long-range transport, aerosol particles may influence the climate by interfering directly with atmospheric radiative processes (Haywood et al., 2003; IPCC, 2007) and indirectly by modifying the distribution and physical properties of clouds (Lohmann et al., 2004). All these direct and indirect effects depend on aerosol particle properties : particle number 
concentration, number size distribution, chemical composition, mixing state and hygroscopic property (Roberts et al., 2001; Wang et al., 2011).

The aerosol parameters influencing the radiative balance and the properties of clouds remain uncertain (Adams et al., 2002; Kaufman et al., 2002; Spichtinger et al., 2008). Moreover, Europe is under the influence of polluted air masses from industrial countries as well as clean air masses from polar regions (Birmili et al., 2001). The mixing of these different types of air mass may lead to a regional mixed plume with modified properties compared to the non-mixed plumes. In particular the atmospheric residence time of pollution and the radiative effect of pollution aerosols are expected to be modified (Andreae et al., 1997). The AeroCom exercise (Kinne et al., 2006; Schulz et al., 2006; Textor et al., 2006) shows the high variance of the vertical aerosol dispersion between the different models involved (Textor et al., 2006). These differences significantly contribute to uncertainties in the estimation of aerosol lifetimes in the atmosphere, which, in turn, impacts their climate effect. Measurements of aerosol properties performed at ground sites are numerous, facilitating model comparisons at the surface, while in situ column measurements of aerosol properties are sparse (Petzold et al., 2002; Morgan et al., 2009, 2010).

These results constitute one of the few studies presenting observations over Europe of the simultaneous aerosol measurements of physical, chemical, optical and hygroscopic properties performed on board the ATR- 42 in the boundary layer (BL) as well as in the lower free troposphere (LFT). The EUCAARI (European Aerosol Cloud Climate and Air Quality Interactions; Kulmala et al., 2009) campaign was performed in May 2008 and included the deployment of five European instrumented research aircrafts (German DLR Falcon-20, the British FAAM Bae-146 and NERC Dornier, and the French ATR-42 and Falcon-20 from Météo-France).

During the campaign a variety of clean marine and polluted continental air masses were encountered, and some of the key aerosol properties associated with these particular air masses are documented and reported here. Moreover, distinct layers, such as the boundary layer and the lower free troposphere, could be sampled during the same flight and over different surface types (land/sea). The results of that kind of investigation are likely to be of significant interest to both the process-modelling community and the large-scale modelling community.

\section{Aircraft and instrumentation}

To improve our understanding of processes related to atmospheric aerosol physics and chemistry, from aerosol formation to the overall aerosol-cloud-climate scale, the French ATR-42 research aircraft performed a total of 22 research flights during May 2008. The ATR-42 operated by SAFIRE (Service des Avions Francais Instrumentés pour la Recherche en Environnement) was based at Rotterdam airport in the Netherlands for the duration of the EUCAARI intensive observation period. The 22 research flights (RF) were grouped into six different types of flights, according to flight plans and scientific missions, as described in Fig. 1. The scientific objectives of the RF type 1 flights were to specify origins and regional characteristics of the air masses sampled at Cabauw. The RF type 2 flights, close to the coastline, were performed to better understand the events of new particle formation occurring near the coastline of the North Sea. The goals of type 3, 4, 5 and 6 research flights aimed at studies related to aerosol properties along a quasi-Lagrangian flight track: west-east and north-south transects, most of the time in coordination with the British Bae-146, DLR -Falcon 20 flights and ground sites. Fourteen (RF42, RF44, RF47, RF49, RF51, RF52, RF55, RF56, RF57, RF58, RF59, RF60, RF62, RF63) out of the 22 flights performed during the campaign were used in this study, while the other eight flights were dedicated to observation of new particle formation events (Crumeyrolle et al., 2010).

The instrumental payload of the French research aircraft ATR-42 was particularly designed for aerosol-cloud interaction study as partially discussed in previous studies (Crumeyrolle et al., 2008; Matsuki et al., 2010b). The aerosol instrumentation performed the particle sampling via the ATR42 community aerosol inlet (CAI). The isokinetic CAI was based on the construction by the University of Hawai'i and is equipped with a shrouded solid diffuser inlet designed by A. Clarke and modified by Météo-France. This inlet has a $50 \%$ sampling efficiency $\left(D_{\mathrm{p}_{50} \%}\right)$ for particle diameter around $5 \mu \mathrm{m}$ (McNaughton et al., 2007). Diffusional losses (relevant below $100 \mathrm{~nm}$ ) of particles during transport in sampling lines were taken into account using respective equations described in Baron and Willeke (2001); see also von der Weiden et al. (2009). Moreover, the particle size distribution has been corrected using the equivalent length method, assuming a $7.1 \mathrm{~m}$ pipe length, described by Wiedensohler et al. (2012).

A scanning mobility particle sizer (SMPS) was used to measure the number size distribution of aerosol particles with diameters from 0.02 to $0.5 \mu \mathrm{m}$. This instrument consisted of a differential mobility analyser (DMA) as described by Villani et al. (2007) and a CPC (TSI model 3010) for particle detection downstream of the DMA. The DMA sheath flow rate was controlled with a critical orifice in a closed-loop arrangement (Jokinen et al., 1996). Typically the scan time yielding one complete number size distribution - was chosen to be $90 \mathrm{~s}$. The used SMPS system has undergone intercomparison within the frame of the European Supersites for Atmospheric Aerosol Research (EUSAAR) project and has been evaluated in the particle mobility size spectrometer harmonization paper of Wiedensohler et al. (2012). In parallel, there was another set of SMPS and an optical particle counter (OPC) measuring particles downstream of a thermodesorption column (same column as modeled/described in 


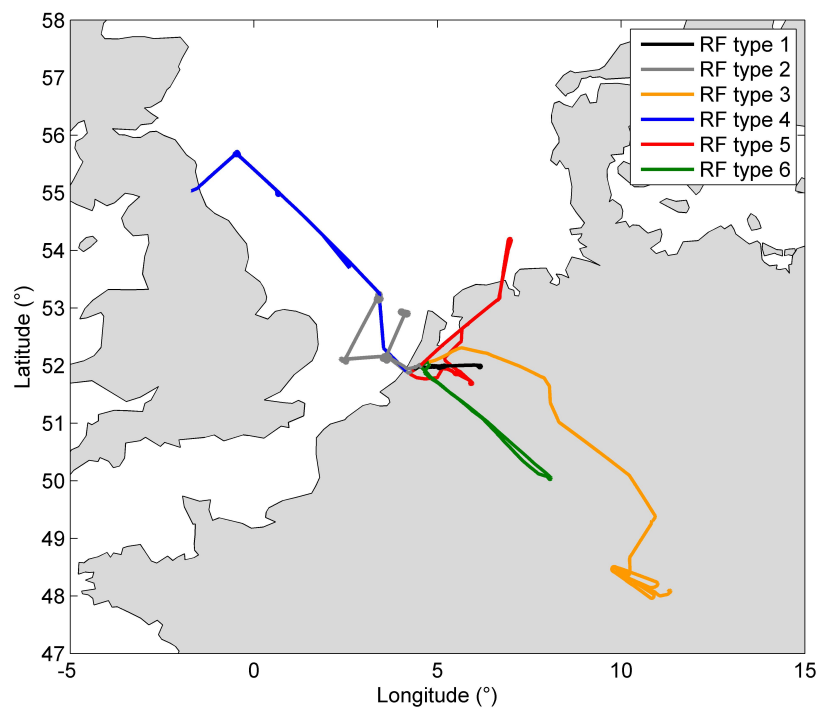

Fig. 1. Different types of research flight (RF) plans performed during the EUCAARI intensive observation campaign in May 2008.

Villani et al., 2007, and subsequently presented in Matsuki et al., 2010a; Quennehen et al., 2011) wherein the particles were heated up to $280^{\circ} \mathrm{C}$. Comparison of the particle size distributions (in number or volume) of the aerosol after being heated versus measurements of the untreated aerosol provides indirect information on the bulk aerosol composition. Particles "surviving" exposure to $280^{\circ}$ will be denoted throughout this paper as refractory particles (e.g. sea salt, soot, mineral dust); otherwise the particles should be mainly composed of volatile species (e.g. ammonium nitrate, ammonium sulphate, sulfuric acid and most organic compounds). Scattering coefficients were calculated using the Mie model (Bond et al., 2006) for the entire campaign (provided in Supplement Fig. 1). The comparison to the scattering coefficient measured on-board the ATR-42 show good correlation (slope around 0.83 and $R^{2}=0.77$ ). At the end of the campaign, a dust plume coming from Africa reached the north of Europe and was observed by the ATR-42. Removing the dust plume event from the comparison increases the square correlation coefficient to 0.96 with a slope calculated around 1.3. These results give us additional confidence on the number size distribution measurements.

Two condensation particle counters (CPC, TSI model 3025 and 3010; McMurry et al., 2000) were used to measure total ambient aerosol concentrations $\left(N_{3}\right.$ and $N_{10}$, respectively). The $50 \%$ detection diameter is larger than 3 and $10 \mathrm{~nm}$ for each CPC, respectively (Mertes et al., 1995; Stolzenburg et al., 1991). The comparison of the total concentration measured by the SMPS and by the CPC 3010 shows good correlation $\left(R^{2}>0.9\right.$ with a slope of about 1.03, provided in Supplement Fig. 2). Overall, the CPC 3010 number concentrations are higher (by 10-20\%) than the concentrations deduced from SMPS number size distributions, thus suggesting a non-negligible concentration of ultra-fine particles (in the 10-20 nm diameter range) that are not measured by the SMPS.

The Cloud Condensation Nuclei Counter (CCNC) used in this study was a continuous-flow streamwise thermalgradient CCN counter, commercially available from Droplet Measurement Technologies, Inc. (DMT, model no. CCN100). The design and operating principles of the instrument are based on Roberts and Nenes (2005). The aerosol sample enters the column at the top centre of the column, and particles with a critical supersaturation less than the centreline supersaturation are activated as $\mathrm{CCN}$. The residence time in the column (6-12 s, depending on flow rate) enables the activated particles to grow to droplets that are sufficiently large $(>1 \mu \mathrm{m})$ to be detected separately from unactivated particles (usually $<1 \mu \mathrm{m}$ ). An OPC at the exit of the column determines the number concentration and size distribution of droplets in the size range of $0.75-10 \mu \mathrm{m}$. Droplets larger than $1 \mu \mathrm{m}$ are considered to be activated CCN. The supersaturation was set at $0.4 \%$ during the whole field campaign.

A Time-of-Flight Aerosol Mass Spectrometer (C-ToFAMS; Drewnick et al., 2005; Canagaratna et al., 2007) was used to analyse the non-refractory particle species, where non-refractory materials include all species that evaporate in $100 \mu$ s under AMS working conditions (Drewnick et al., 2005). In practice, non-refractory material includes species such as ammonium sulfate and bisulfate, ammonium chloride, ammonium nitrate, and organic compounds but excludes black carbon, crustal materials, and sea salt/sodium chloride. Non-refractory species internally mixed with refractory species (e.g. organics internally mixed with black carbon) can be quantitatively detected with the AMS (Katrib et al., 2005; Slowik et al., 2004). The non-refractory particle species that are vaporized at the heated surface (about $600^{\circ} \mathrm{C}$ ) are then subjected to electron impact ionization, which forms positive ions that are analysed with a mass spectrometer. The upper $50 \%$ cut-off diameter of the on-board AMS is about $500 \mathrm{~nm}$. The ionization efficiency (IE) calibrations were performed prior to and after the campaign as well as 5 times during the campaign period. The resulting IE showed a good stability and reproducibility $(<6 \%$ decrease, caused by detector ageing throughout the campaign). The data shown here are corrected by collection efficiency (CE) factors which were obtained according to Crosier et al. (2007). All flight data were treated according to procedures provided within the standard AMS analysis software "Squirrel" (SeQUential Igor data RetRiEvaL version 1.48; Allan et al., 2003) implemented with Wavemetrics Igor Pro (version 6.12) and in accordance with the standards defined and used by the Aerodyne AMS operators community at the time when these data were treated (http://cires.colorado.edu/ jimenez-group/wiki/index.php/FieldDataAnalysisGuide). 


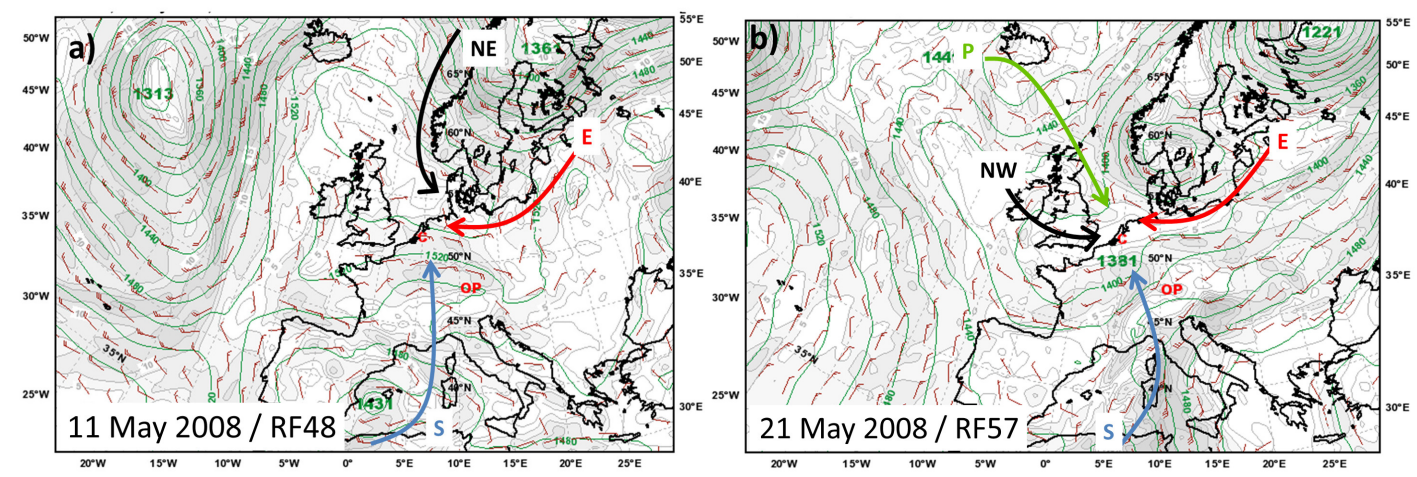

Fig. 2. Geopotential and wind speed at $850 \mathrm{hPa}$ for (a) anticyclonic and (b) cyclonic conditions. The arrows correspond to a mean direction of air mass trajectories approaching the measurement location. The different air mass sectors are NW: north-west Europe; S: south Europe; NE: north Europe; E: east Europe; and P: polar; they correspond to cases outlined in Tables 1-4 and in the next figures.

\section{Classification of air masses}

In order to determine the geographical origins and the history of air masses, retroplume dispersion calculations are performed using the FLEXPART model (version 8.0) that is extensively described in Stohl et al. (1998) and Stohl et al. (2005). FLEXPART was driven by 6-hourly ECMWF operational analysis data interleaved with operational forecasts every $3 \mathrm{~h}$ (ECMWF, 1995). The model accounts for small-scale turbulence by superimposing stochastic motions on grid-scale winds (Stohl and Thomson et al., 1999) and convection using the scheme of Emmanuel and ZivkovicRothman (1999). FLEXPART was initialized for segments - corresponding to changes in ATR-42 position and altitude - along the flight track of the ATR-42 - and calculated air mass trajectories over 20 days backward in time.

FLEXPART results deliver potential emission sensitivity (PES) fields. The PES is based on transport calculations for an inert substance, ignoring removal processes that would reduce the sensitivity. Thus by vertically integrating PES values, these fields describe the overall transport of air masses during the 20 days before being sampled by the aircraft instrumentation. We used the column-integrated PES fields to categorize the sampled air into five sectors of air mass origin. All retroplumes were classified according to their predominant PES values over one of the five sectors before being sampled with the ATR-42 instruments (see Fig. 1). These five sectors, similar to previous studies (Birmili et al., 2001; Tunved et al., 2005), were chosen because of different aerosol sources in these regions (Fig. 2).

The following sectors were used for classification of the measurements:

1. North-west European (NW) sector corresponding to air masses passing over the Atlantic and the United Kingdom.
2. South European (S) sector corresponding to air masses passing over North Africa, the Atlantic Ocean and the Mediterranean or southern Europe.

3. North-east European (NE) sector corresponding to air masses coming from Scandinavia and passing over the North Sea.

4. East European (E) sector corresponding to air masses passing over continental Europe.

5. Polar $(\mathrm{P})$ sector corresponding to air masses originating from the polar region with expected low particle content.

The meteorological parameters averaged over all 12 flights performed during the campaign, for the five air mass sectors, are given in Table 1. The relative frequency (in percent) at which the air masses originated from a specific air sector are also reported in Table 1 .

A recent study (Hamburger et al., 2010) highlights a strong relationship between the meteorological conditions and the aerosol properties during the whole LONGREX (LONG Range EXperiment) project of the EUCAARI campaign. An anticyclonic blocking event occurred during the first half of May 2008 (1-15 May) and led to accumulation of particulate pollutants within the boundary layer, while the second half of the month (16-31 May) was dominated by westerly flow and passage of frontal systems (called cyclonic period hereinafter) that produced precipitation and led to a cleansing of the atmosphere. Thus, anticyclonic (high pressure, HP) and cyclonic (low pressure, LP) conditions will be distinguished in this study (Table 1). In addition, during each flight, one or two vertical soundings were performed at the beginning and/or at the end of the flight, allowing for a characterization of the vertical evolution of the thermodynamical and microphysical parameters. From these soundings, the inversion level, corresponding to the top of the BL and the bottom of the LFT, determined the mixing layer height. Generally, the 
Table 1. Averaged meteorological parameters observed in the boundary layer (BL) and in the lower free troposphere (LFT) for different episodes during anticyclonic (HP) and cyclonic (LP) conditions and for the different air mass sectors (NW: north-west Europe; S: south Europe; NE: north Europe; E: east Europe; P: polar). - = not observed.

\begin{tabular}{ll|rr|rr|rr|rr}
\hline & & \multicolumn{2}{|c|}{ RH (\%) } & \multicolumn{2}{|c|}{ Pot. $T(\mathrm{~K})$} & \% of time occurring & \multicolumn{2}{c}{ Altitude range (m) } \\
\cline { 3 - 10 } & & HP & LP & HP & LP & HP & LP & HP & LP \\
\hline BL & NW & $64(8)$ & - & $290.4(0.8)$ & - & 33 & - & $\leq 1500$ & - \\
& S & - & $76(16)$ & - & $299.3(2.4)$ & - & 13 & - & $\leq 1400$ \\
& NE & - & $66(14)$ & - & $286.4(1.5)$ & - & 65 & - & $\leq 1600$ \\
& E & $45(11)$ & $22.5(11)$ & $297.2(2.5)$ & $292.5(5.9)$ & 67 & 19 & $\leq 1600$ & $\leq 1200$ \\
& P & - & $74(9)$ & - & $285.8(0.1)$ & - & 3 & - & $\leq 1200$ \\
\hline LFT & NW & - & - & - & - & - & - & - & - \\
& S & - & $54(16)$ & - & $306.3(4.3)$ & - & 54 & - & $1600-3000$ \\
& NE & $15(5)$ & $20(4)$ & $310.2(0.1)$ & $297.4(1.1)$ & 4 & 23 & $3000-5000$ & $2500-3000$ \\
E & $43(18)$ & $67(6)$ & $300.5(5.6)$ & $306.8(2.3)$ & 96 & 18 & $1600-4000$ & $2500-3000$ \\
& P & - & $10(4)$ & - & $298.7(1.7)$ & - & 5 & - & $2800-3100$ \\
\hline
\end{tabular}

mixing layer height was $<1600 \mathrm{~m}$ during the whole campaign. The altitude ranges performed by the ATR- 42 for each air mass type characterization are included in Table 1.

During anticyclonic conditions (HP), air masses were originating from east (E, in the BL and in the LFT), north-west (NW, in the BL only) and north-east (NE, in the LFT only). In contrast during cyclonic conditions, air masses were originating from E, P, S and NE (in the BL and in the LFT). Air masses sampled by the ATR-42 instrumentation in both layers were more frequently coming from $\mathrm{E}$ during anticyclonic conditions (HP). During cyclonic conditions (LP), NE air masses were more frequently observed in the BL, and $\mathrm{S}$ air masses were more frequently observed in the LFT.

In the boundary layer, the potential temperatures of $\mathrm{S}$ air masses (> 299.3 K) were significantly higher compared to other air masses. Moreover, the averaged relative humidity $(\mathrm{RH})$ values were beyond $60 \%$ in the BL except when air masses were coming from $\mathrm{E}(<45 \%)$. Contrarily, these air masses observed in the LFT were associated with the highest values of $\mathrm{RH}(>43 \%)$.

\section{Results and discussion}

The measured $\mathrm{CN}$ concentrations and the aerosol optical properties were first analysed to better characterize the pollution level of the five different air mass sectors and to highlight the difference between the boundary layer from the lower free troposphere.

\subsection{Aerosol number concentration}

Median values of particle number concentration for the size classes $N_{3-10}, N_{10}, N_{50}$ and $N_{100}$ (i.e. particles with diameter between 3 and $10 \mathrm{~nm}$ and larger than 10,50 , and $100 \mathrm{~nm}$, respectively) are given in Table 2 . The difference in the acquisition frequency of the CPC $(1 \mathrm{~Hz})$ and SMPS $(0.01 \mathrm{~Hz})$
Table 2. Median number concentration in the boundary layer (BL) and in the lower free troposphere (LFT) during anticyclonic (HP) and cyclonic (LP) conditions for the different air mass sectors (NW: north-west Europe; S: south Europe; NE: north Europe; E: east Europe; P: polar). $N_{10}$ : $\mathrm{CN}$ concentration for particles larger than 10 $\mathrm{nm}$ measured with the CPC $3010 ; N_{50}$ : CN concentration for particles larger than $50 \mathrm{~nm}$ measured with the SMPS; and $N_{100}$ : CN concentration for particles larger than $100 \mathrm{~nm}$ measured with the PCASP.

\begin{tabular}{ll|rr|rr|rr}
\hline & & \multicolumn{2}{|c|}{$N_{10}\left(\mathrm{~cm}^{-3}\right)$} & \multicolumn{2}{c|}{$N_{50}\left(\mathrm{~cm}^{-3}\right)$} & \multicolumn{2}{c}{$N_{100}\left(\mathrm{~cm}^{-3}\right)$} \\
\cline { 3 - 8 } & & HP & LP & HP & LP & HP & LP \\
\hline BL & NW & 1300 & - & 150 & - & 112 & - \\
& S & - & 4800 & - & 5400 & - & 3192 \\
& NE & - & 5970 & - & 2900 & - & 1680 \\
& E & 5490 & 3135 & 3240 & 5820 & 2323 & 4542 \\
& P & - & 7090 & - & 1390 & - & 1000 \\
\hline \multirow{2}{*}{ LFT } & NW & - & - & - & - & - & - \\
& S & - & 930 & - & 660 & - & 477 \\
& NE & 660 & 400 & 80 & 260 & 32 & 161 \\
E & 865 & 920 & 680 & 940 & 301 & 682 \\
P & - & 440 & - & 325 & - & 253 \\
\hline
\end{tabular}

causes some discrepancy in the comparison of the $N_{10}$ (CPC total concentration) and $N_{50}$ (integration of the SMPS number size distribution). This discrepancy is in average in the same range than the uncertainty of both instruments.

In Fig. 3, $N_{10}$ concentrations are presented and separated according to cyclonic (LP) and anticyclonic (HP) conditions and according to the origin of the air mass, in the BL and LFT. A large variability in CN concentration can be observed in Fig. 3 and in Table 2. The total aerosol concentrations $\left(N_{10}\right)$ are between 1300 and $7090 \mathrm{~cm}^{-3}$ within the BL and between 400 and $930 \mathrm{~cm}^{-3}$ within the LFT. These results are consistent with other airborne measurement studies 

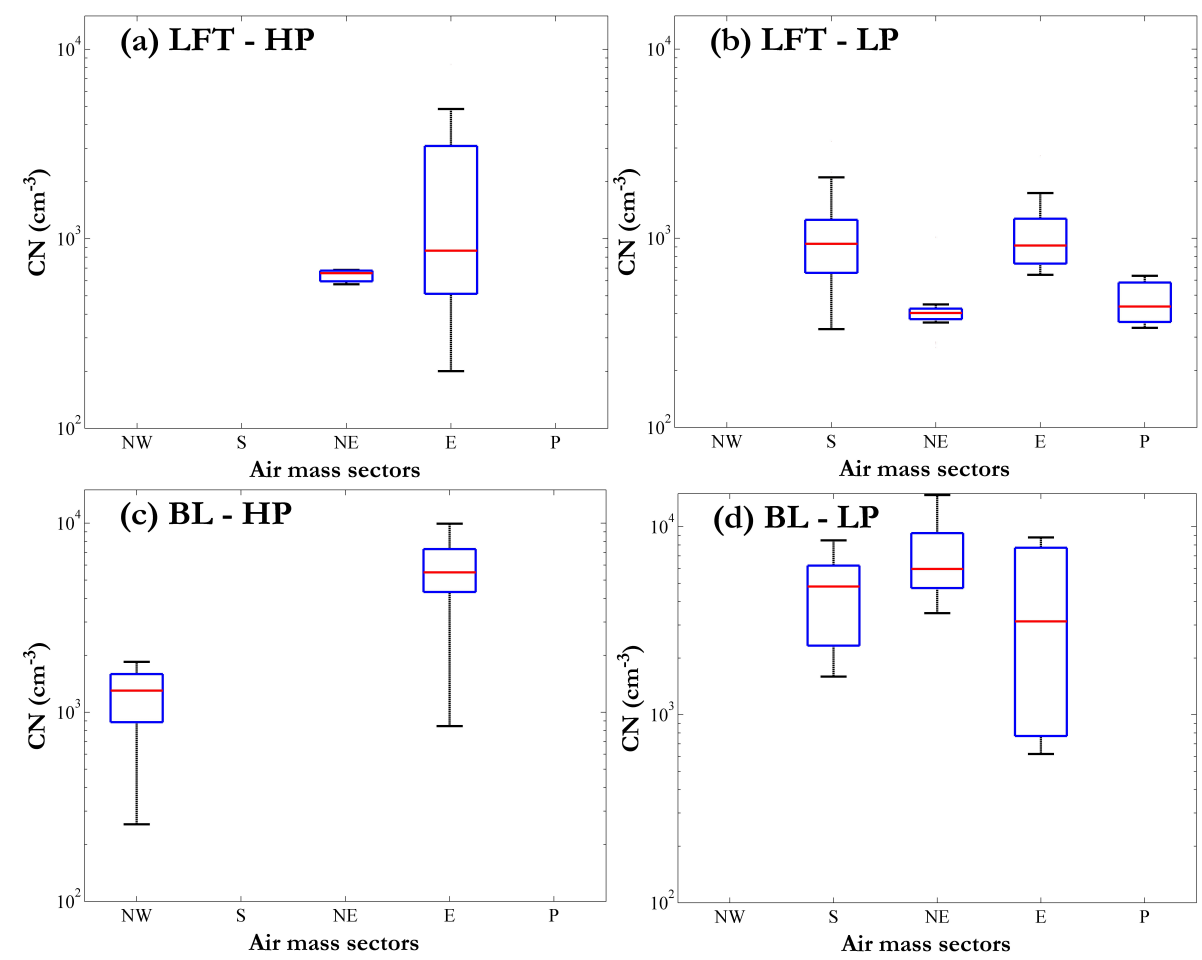

Fig. 3. Total $\mathrm{CN}$ concentration $\left(D_{\mathrm{p}}>10 \mathrm{~nm}\right)$ as a function of the air mass origin (NW: north-west Europe; S: south Europe; NE: north Europe; E: east Europe; P: polar) in the lower free troposphere (FT) during anticyclonic (HP, a) and during cyclonic (LP, b) conditions as well as in the boundary layer (BL) during anticyclonic (HP, c) and during cyclonic (LP, d) conditions. Lower and upper limits of the box correspond to $25 \%$ and $75 \%$ percentiles, bottom and top whiskers the $5 \%$ and $95 \%$. Middle bars indicate the median.

(Hamburger et al., 2010; Mirme et al., 2010). As the sources of primary particles are mostly located in the $\mathrm{BL}$, the particle concentrations are higher in the BL compared to the LFT.

$N_{10}$ concentrations are more variable in the BL (especially for air masses coming from the $\mathrm{E}$ sector during LP conditions) mainly due to the spatial heterogeneities of particle sources and the intensity of the removal processes. Differences between BL and LFT observations are particularly related to the lifetime of particles in these layers. Indeed, in the boundary layer, particles are freshly emitted with different properties as a function of the emission source, while within the LFT long-range transportation, cloud processing, coagulation, and sedimentation, etc., (Raes et al., 2000; Williams et al., 2002) tend to mix all aerosol together and to modify initial aerosol properties. However, the variability of the $N_{10}$ concentrations measured in the LFT for the E sector during HP conditions is large compared to other air mass sectors. Due to the high occurrence time of the E sector (96\%), the measurement period covers different meteorological conditions (wind speed, cloud presence, etc.) and different aerosol source strengths (week days, weekend days).

Due to the residence of air masses over important industrial areas in Poland, northern Germany, Spain and France, air mass coming from the eastern and southern part of Europe (E and S) are supposed to be the more polluted. As expected the median $N_{10}$ concentrations in these two air mass sectors are higher compared to those in the other air mass sectors except in the BL during cyclonic conditions. Indeed, the $N_{10}$ concentrations associated to the cleanest air mass sectors ( $P$ and NE) are surprisingly high. In fact, these high values are caused by the growth of ultra-fine mode particles $\left(N_{3-10}\right)$ which reach $5400 \mathrm{~cm}^{-3}$ in $\mathrm{P}$ air masses and $3200 \mathrm{~cm}^{-3}$ in NE air masses, while the $N_{50}$ are relatively low (1390 and $2900 \mathrm{~cm}^{-3}$, respectively; see Table 2).

\subsection{Aerosol number and volume size distribution}

Average particle number size distributions obtained from the SMPS are shown in Fig. 4. In general, these number size distributions of particles were averaged according to air mass origins and subsequently fitted with a maximum of 3 log-normal distributions. Table 3 presents the characteristics of the log-normally fitted number size distributions for the population of aerosol measured during the campaign. Three of the six particle number size distributions observed in the BL during the whole campaign are trimodal (Fig. 4), composed of an ultra-fine mode $\left(D_{\mathrm{uf}}<30 \mathrm{~nm}\right)$, an Aitken mode $\left(30<D_{\text {Ait }}<60 \mathrm{~nm}\right)$ and an accumulation mode $\left(100<D_{\text {Acc }}<175 \mathrm{~nm}\right)$. In the LFT, aerosol number size distributions are bimodal and composed of an Aitken and an accumulation mode. The ultra-fine mode, only observed 

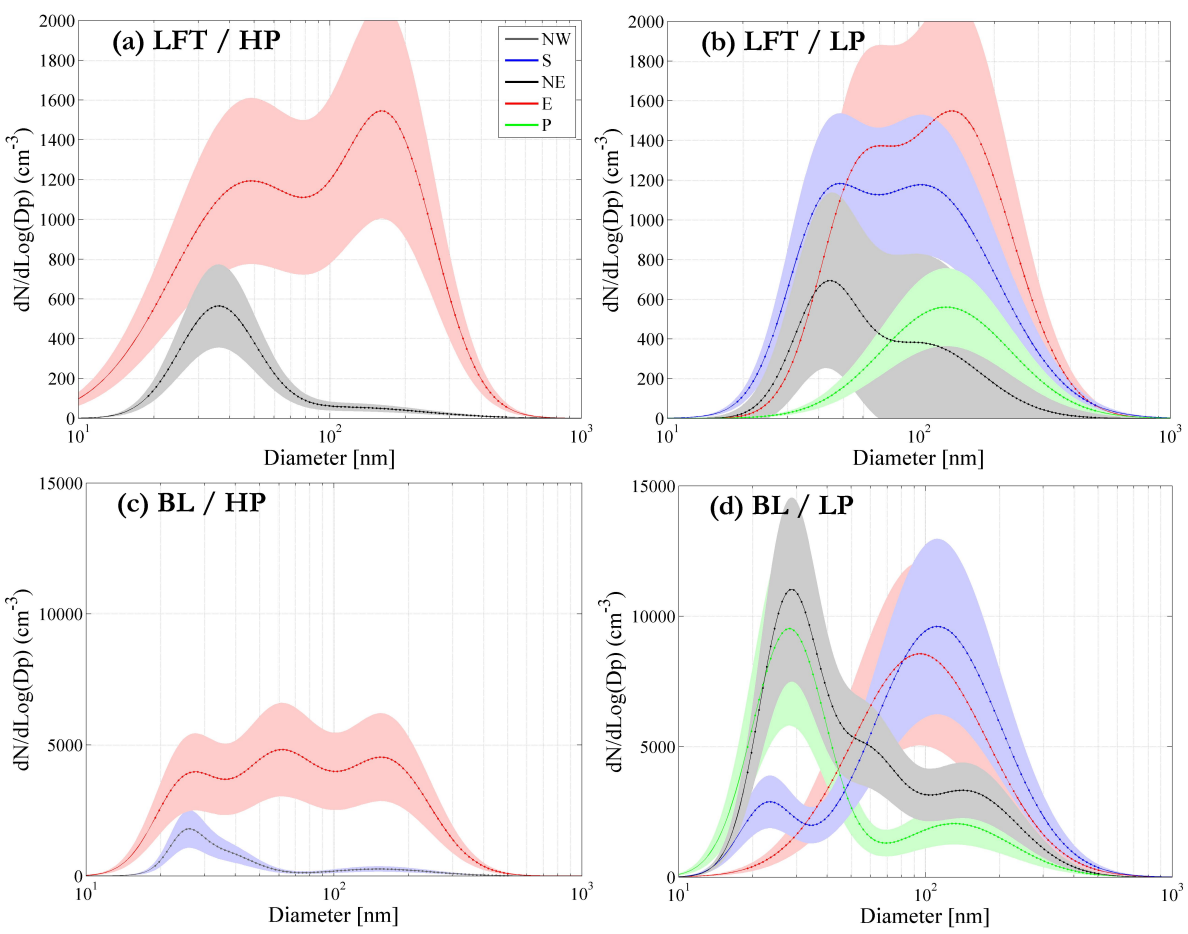

Fig. 4. Particle number size distribution $\left(10 \mathrm{~nm}<D_{\mathrm{p}}<500 \mathrm{~nm}\right)$ as a function of the air mass origin (NW: north-west Europe; S: south Europe; NE: north Europe; E: east Europe, P: polar) in the lower free troposphere during anticyclonic (HP, a) and cyclonic (LP, b) conditions as well as in the boundary layer during anticyclonic (HP, c) and during cyclonic (LP, d) conditions. The shading areas correspond to the standard deviation $(1 \sigma)$ of the measurements.

in the boundary layer, is centred between 22 and $28 \mathrm{~nm}$ during anticyclonic conditions (HP, Fig. 4c) as well as during cyclonic conditions (Fig. 4d). The concentrations of these ultra-fine mode particles are high $\left(>3000 \mathrm{~cm}^{-3}\right)$ in clean air masses (NE and $\mathrm{P}$ ) most likely due to secondary aerosol formation and intermediate (around $1000 \mathrm{~cm}^{-3}$ ) in polluted air masses (E and $S$ ), which might be related to the secondary aerosol formation as well as some primary emissions (e.g. traffic emission).

The comparison of the aerosol number size distribution measured on-board the ATR-42 in the boundary layer with the ones previously measured in Europe by Birmili et al. (2001) and Asmi et al. (2011) show strong similarities. Indeed, the aerosol number size distributions in these two studies are trimodal (aged nucleation, Aitken, accumulation modes), and the concentrations as well as the width of these log-normal distributions are similar. As reported by Tunved et al. (2005), the number size distributions of the particles show an increase in Aitken and accumulation mode number concentrations as the continental influence increases.

The Aitken mode is observed both in clean and polluted air masses in the BL as well as in the LFT. In the BL, the log-normal characteristics of the Aitken mode are similar: the median diameters are between 33.5 and $59.5 \mathrm{~nm}$, the standard deviation ranges between 1.35 and 1.48 and the concentrations are between 327 and $1975 \mathrm{~cm}^{-3}$. In the LFT, the mean diameters of the Aitken mode (between 35.8 and $55.3 \mathrm{~nm}$ ) are similar to those observed in the BL. The mean diameter is usually larger in the LFT than in the BL due to dynamical processes (condensation or coagulation). Therefore, the later results suggest a short residence time (compared to usual observations) of the aerosol in the LFT.

The large difference found for $N_{10}$ concentrations between the two layers (BL and LFT) is also observed for the concentrations of accumulation mode particles. Indeed, these concentrations are higher than $1200 \mathrm{~cm}^{-3}$ in the BL (except for NW air masses), comparable with ground site observations reported in Hamburger et al. (2010) and lower than $850 \mathrm{~cm}^{-3}$ in the LFT. However, in S air masses, accumulation mode particle number concentrations are high in both the BL and the LFT. Begue et al. (2002) used the ATR-42 measurements associated with a mesoscale model (Meso-NH) to depict the transport of dust particles from North Africa during EUCAARI (S air masses). This dust plume stayed over Europe for four days and sedimented via precipitation and may explain the highly concentrated accumulation mode of the $\mathrm{S}$ air masses in the BL and in the LFT.

A comparison of the median diameter observed during both meteorological conditions highlights that the median diameter of the accumulation mode is larger in the lower free troposphere during anticyclonic conditions (HP) than during low-pressure conditions (LP), by a factor between 1.1 
Table 3. Log-normal characteristics of the number size distributions shown in Fig. 4 for the different air mass sectors (NW: north-west Europe; S: south Europe; NE: north Europe; E: east Europe; P: polar). $N_{i}$ represents the concentration, $D_{i}$ is the geometric mean diameter and $\sigma_{i}$ is the standard deviation of the particle mode $i$ (mode $1=$ nucleation; mode $2=$ Aitken; mode $3=$ accumulation).

\begin{tabular}{ll|rrr|rrr}
\hline & & \multicolumn{3}{|c|}{ HP } & \multicolumn{3}{|c}{ LP } \\
\cline { 3 - 8 } & Mode i & $N_{i}\left(\mathrm{~cm}^{-3}\right)$ & $D_{i}(\mathrm{~nm})$ & $\sigma_{i}$ & $N_{i}\left(\mathrm{~cm}^{-3}\right)$ & $D_{i}(\mathrm{~nm})$ & $\sigma_{i}$ \\
\hline BL NW 1 & 186 & 25 & 1.16 & - & - & - \\
& NW 2 & 327 & 33 & 1.37 & - & - & - \\
NW 3 & 138 & 151 & 1.6 & - & - & - \\
S 1 & - & - & - & 735 & 23 & 1.29 \\
S 3 & - & - & - & 6150 & 112 & 1.79 \\
NE 1 & - & - & - & 3280 & 28 & 1.32 \\
NE 2 & - & - & - & 1360 & 57 & 1.35 \\
NE 3 & - & - & - & 1750 & 146 & 1.63 \\
E 1 & 1095 & 25 & 1.34 & - & - & - \\
E 2 & 1975 & 59 & 1.48 & 5900 & 95 & 1.88 \\
E 3 & 1905 & 164 & 1.49 & - & - & - \\
P 1 & - & - & - & 3540 & 28 & 1.40 & \\
P 3 & - & - & - & 1205 & 131 & 1.71 & \\
NW 1 & - & - & - & - & - & - \\
LFT 2 & - & - & - & 260 & 40 & 1.39 \\
S 3 & - & - & - & 835 & 106 & 1.91 & \\
NE 2 & 215 & 36 & 1.42 & 190 & 42 & 1.34 \\
NE 3 & 45 & 116 & 2 & 220 & 104 & 1.70 & \\
E 2 & 895 & 47 & 2 & 380 & 55 & 1.41 \\
E 3 & 605 & 175 & 1.52 & 835 & 141 & 1.65 & \\
P 3 & - & - & - & 360 & 128 & 1.80 & \\
\hline
\end{tabular}

and 1.7. These changes are quantitatively consistent with the results shown in Hamburger et al. (2010). Moreover, in two air masses under cyclonic conditions ( $\mathrm{E}$ in the $\mathrm{BL}$ and $\mathrm{P}$ in the LFT), the aerosol number size distributions could be represented by only one broad $(\sigma>=1.8)$ accumulation mode $(95-128 \mathrm{~nm})$. These observations indicate that particles resided a longer time in the atmosphere during which they may grow by condensation, by interacting with clouds or by coagulation and gases condensation.

For each aerosol number size distribution presented in Fig. 4, the total volume concentration was calculated by integrating the particle volume size distribution, assuming a spherical shape for all the particles. These total volume concentrations are reported in Table 4 as well as the volume concentrations of refractory particles similarly calculated from the particle volume size distribution of the heated aerosol population. Significant differences in the calculated volume concentrations are observed for the different air mass sectors. $\mathrm{E}$ air masses passing over industrial and densely populated areas have high aerosol loadings $\left(>9.59 \mu \mathrm{m}^{3} \mathrm{~cm}^{-3}\right.$ in the BL and $>3.95 \mu \mathrm{m}^{3} \mathrm{~cm}^{-3}$ in the LFT) during anticyclonic (HP) as well as during cyclonic (LP) conditions. Interestingly, low aerosol loadings are associated with air masses passing over the United Kingdom in the BL (NW: $0.71 \mu \mathrm{m}^{3} \mathrm{~cm}^{-3}$ ). In the LFT, NE air masses were associated with the lowest volume
Table 4. Overview of total and refractory particle volume concentrations (integrated from the volume size distribution) and volume fraction of refractory material for the different air mass sectors (NW: north-west Europe; S: south Europe; NE: north Europe; E: east Europe; P: polar).

\begin{tabular}{ll|rr|rr|rr}
\hline & & $\begin{array}{c}\text { Total volume } \\
\left(\mu \mathrm{m}^{3} \mathrm{~cm}^{-3}\right)\end{array}$ & \multicolumn{2}{|c|}{$\begin{array}{c}\text { Refractory particle } \\
\text { volume }\left(\mu \mathrm{m}^{3} \mathrm{~cm}^{-3}\right)\end{array}$} & $\begin{array}{c}\text { Refractory } \\
\text { fraction (\%) }\end{array}$ \\
\cline { 3 - 8 } & & HP & LP & HP & LP & HP & LP \\
\hline BL & NW & 0.71 & - & 0.13 & - & 18 & - \\
& S & - & 47.84 & - & 2.90 & - & 6 \\
& NE & - & 8.56 & - & 0.82 & - & 9 \\
& E & 9.59 & 19.31 & 1.44 & 1.70 & 15 & 9 \\
& P & - & 5.32 & - & 0.83 & - & 15 \\
\hline LFT & NW & - & - & - & - & - & - \\
& S & - & 3.48 & - & 1.12 & - & 32 \\
& NE & 0.30 & 0.46 & 0.72 & 0.17 & - & 36 \\
E & 4.11 & 3.95 & 0.64 & 1.10 & 15 & 28 \\
P & - & 1.91 & - & 0.30 & - & 16 \\
\hline
\end{tabular}

concentrations $\left(<0.46 \mu \mathrm{m}^{3} \mathrm{~cm}^{-3}\right)$, consistent with previous results of Van Dingenen et al. (2005).

During $\mathrm{S}$ air mass periods, the total aerosol volume concentration is high in the $\mathrm{BL}\left(47.8 \mu \mathrm{m}^{3} \mathrm{~cm}^{-3}\right)$, as well as in the LFT $\left(3.48 \mu \mathrm{m}^{3} \mathrm{~cm}^{-3}\right.$, comparable to the values reached 

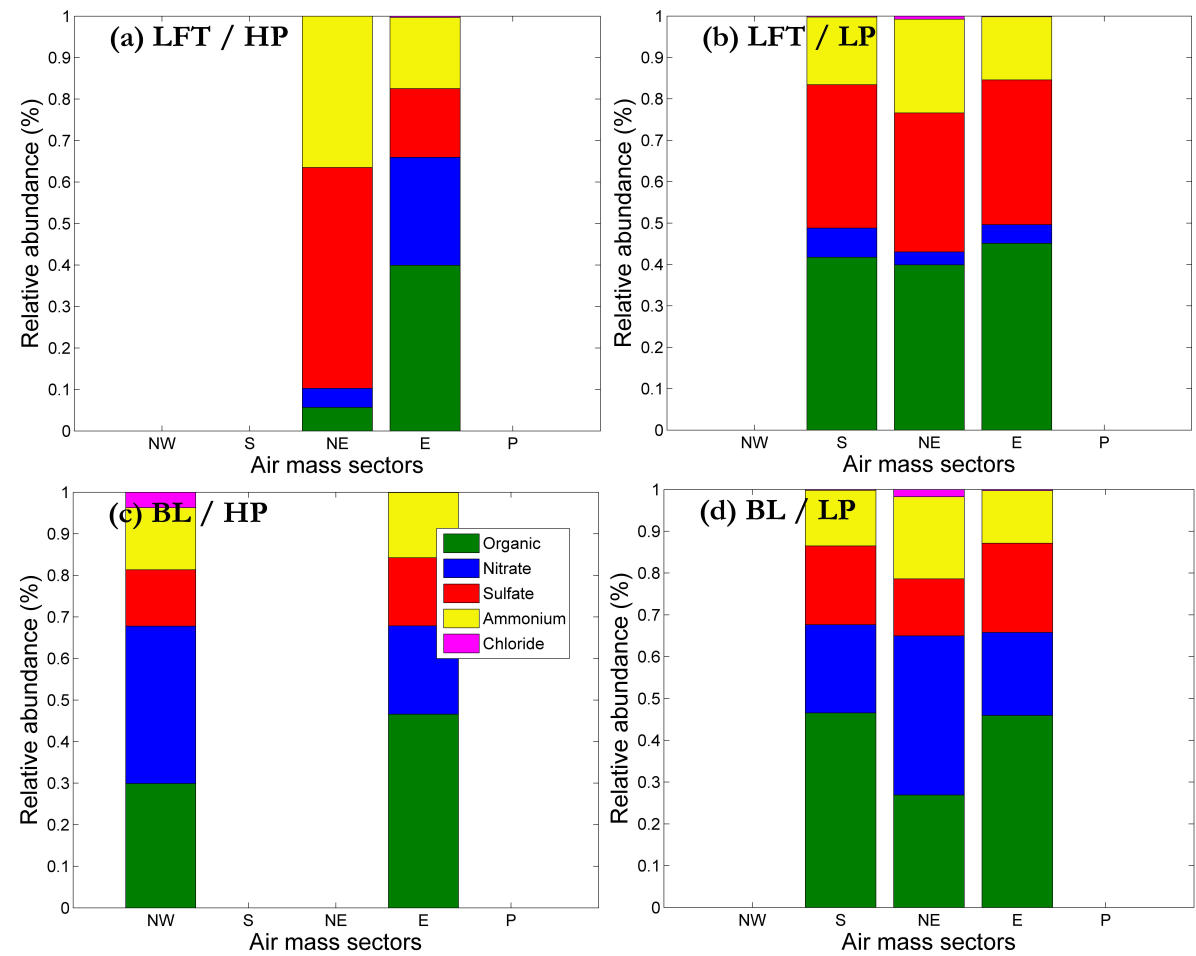

Fig. 5. Bar plot of average relative concentrations of non-refractory submicron aerosol as measured by AMS as a function of the air mass origin (NW: north-west Europe; S: south Europe; NE: north Europe; E: east Europe; P: polar) in the lower free troposphere (LFT) during anticyclonic (HP, a) and cyclonic (LP, b) conditions as well as in the boundary layer (BL) during anticyclonic (HP, c) and cyclonic (LP, d) conditions.

for polluted air masses). Moreover, the refractory aerosol volume concentrations are the highest measured in both layers $\left(2.9\right.$ and $1.12 \mu \mathrm{m}^{3} \mathrm{~cm}^{-3}$, respectively, in the BL and in the LFT), while the refractory fraction is low (6\% in the BL and $32 \%$ in the FT). As shown by Begue et al. (2012), the dust particles transported over Europe were mixed with anthropogenic aerosol and thus modified by volatile materials (i.e. organics). This result may explain the high total volume concentration while the refractory fraction is low.

During cyclonic conditions, the fraction of refractory matter, given by the ratio of the refractory volume over total volume of sampled particles (Table 4), is higher in the LFT than in the BL. As refractory materials are only emitted at the surface, the profile of the refractory material fraction (i.e. gradient increase with the altitude) may be related to aerosol wash-out in the lower layers. Indeed, one can note that the same tendency is not observed during the anticyclonic periods when precipitation events were not encountered.

\subsection{Aerosol chemical composition and mass concentration}

The average relative concentrations for organic, nitrate, sulfate, ammonium and chloride measured by the AMS are given in Fig. 5 as a function of the air mass origin. The mass concentrations of refractory material are estimated by us- ing the number size distribution of particles $\left(D_{\mathrm{p}}<500 \mathrm{~nm}\right)$ sampled downstream of a thermo-desorption column (VSMPS), by assuming that refractory particles are spherical and by using a density of $1.8 \mathrm{~g} \mathrm{~cm}^{-3}$ determined by Slowik et al. (2007). The mass concentrations of refractory and nonrefractory material, corresponding to the sum of the AMS components, are plotted in Fig. 6. The AMS was not working properly during the polar sector periods, thus no measurements are shown either in Fig. 5 or in Fig. 6.

In the BL, two different groups of air mass sectors can be distinguished according to the particle chemical composition, independently of the synoptic conditions: group I (E and $\mathrm{S})$ and group II (NW and NE). For group II, we observe high nitrate concentrations $\left(>5 \mu \mathrm{g} \mathrm{m}^{-3}\right)$ and the chloride concentrations reach 0.61 and $0.25 \mu \mathrm{g} \mathrm{m}^{-3}$ for NW and NE, respectively. Zorn et al. (2008) show that peaks in nitrate, associated with an increase in chloride concentration, may originate from natural (marine aerosol) or anthropogenic sources (industry exhaust). The refractory material concentration is 6 times higher during NE periods $\left(1.48 \mu \mathrm{g} \mathrm{m}^{-3}\right)$ than during NW periods $\left(0.24 \mu \mathrm{g} \mathrm{m}^{-3}\right)$. This reflects the fact that the NE sector is more influenced by anthropogenic aerosol contributions, while marine aerosol contributions are much more important during NW periods. The aerosol relative and absolute chemical compositions of group I are similar to the 

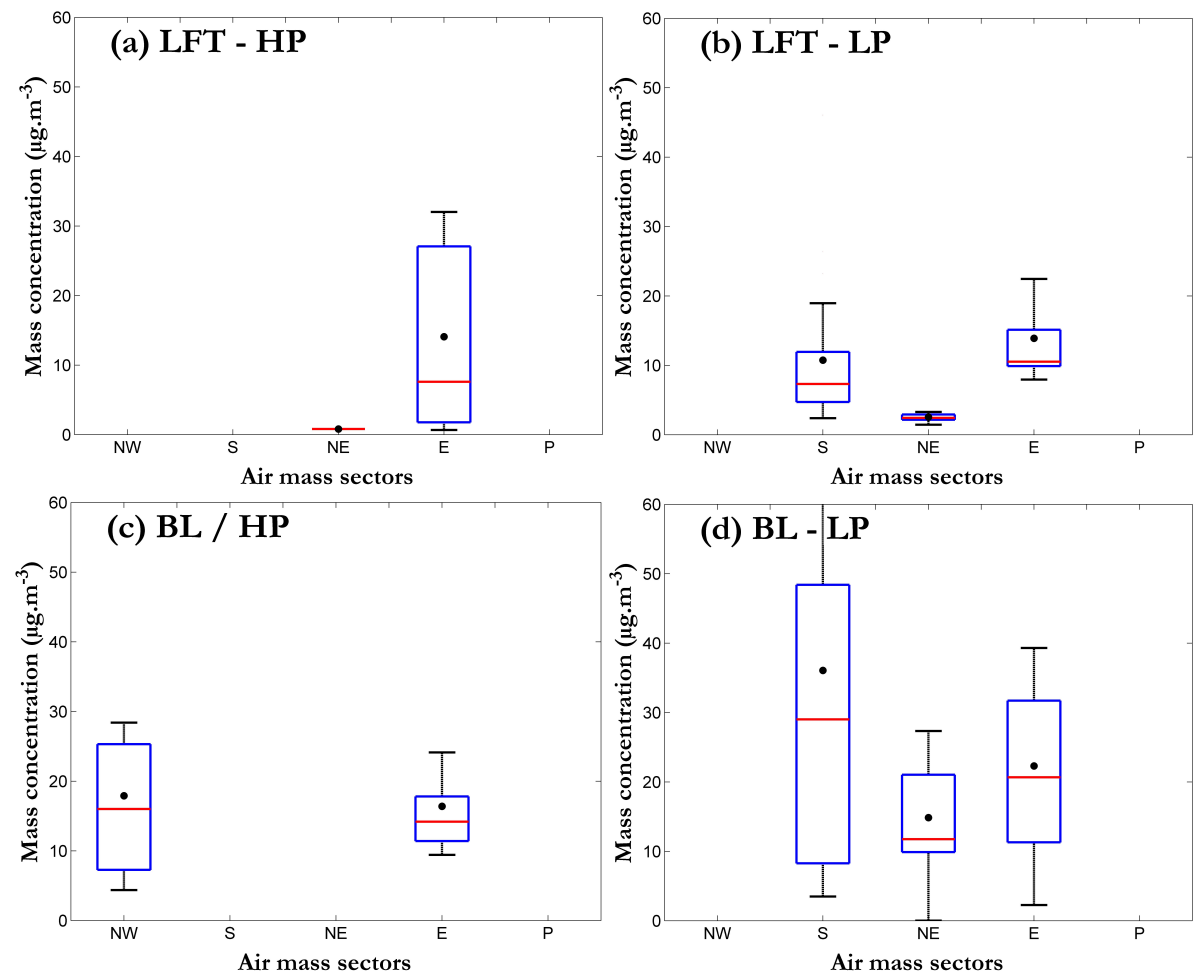

Fig. 6. Mass concentration of submicron non-refractory aerosol as measured by AMS as a function of the air mass origin (NW: north-West Europe; S: south Europe; NE: north Europe; E: east Europe; P: polar) in the lower free troposphere during anticyclonic (HP, a) and cyclonic (LP, b) conditions as well as in the boundary layer during anticyclonic (HP, c) and cyclonic (LP, d) conditions. Lower and upper limits of the box correspond to $25 \%$ and $75 \%$ percentiles, bottom and top whiskers the $5 \%$ and $95 \%$. Middle bars indicate the median. Black points represent the averaged total mass concentration (including the mass of refractory material (exposed to high temperature) derived from the aerosol volume distribution and a density of $1.8 \mathrm{~g} \mathrm{~cm}^{-3}$ ).

one observed over highly polluted urban areas, like Mexico City during the Milagro airborne campaign (DeCarlo et al., 2008). Organics are the major component (about $50 \%$ ) and nitrates are the second most important component $(20 \%)$, consistent with previous studies performed in urban areas (Europe: Putaud et al., 2004; Toronto: Jeong et al., 2011) as well as in remote areas (Germany: Hock et al., 2008; western UK: Morgan et al., 2009). Sulfate and ammonium relative concentrations are about $15 \%$, while the chloride relative concentrations are always lower than $1 \%$. The air masses originating from the $\mathrm{S}$ sector have the highest mass concentration $\left(29 \mu \mathrm{g} \mathrm{m}^{-3}\right)$ and the highest refractory material level $\left(5.24 \mu \mathrm{g} \mathrm{m}^{-3}\right)$, consistent with the highest aerosol volume concentrations in the polluted air masses. In particular, the absolute concentrations of organics reach $18 \mu \mathrm{g} \mathrm{m}^{-3}$, corresponding to values generally observed in different urban areas like Pittsburgh (Zhang et al., 2005), Mexico City (Volkamer et al., 2006) or Zurich (Lanz et al., 2007) and 5 times higher than those reported by Morgan et al. (2009) over the United Kingdom. These high concentrations (total as well as organics concentrations) are related to the transport of dust over urban areas (Begue et al., 2012). Dust particles are mixed with highly polluted air masses (i.e. high concentra- tion of organic gases), leading to the adsorbtion of gases onto dust particles (Falkovich et al., 2001). The NW air masses were found to be much cleaner according to the volume concentration and the refractory material level $\left(0.24 \mu \mathrm{g} \mathrm{m}^{-3}\right)$. However, the total mass concentration $\left(16 \mu \mathrm{g} \mathrm{m}^{-3}\right)$ is still high and corresponds to roughly $50 \%$ of the upper value.

The profiles of the chemical composition for both meteorological conditions show a decrease of the relative fraction of organics and nitrate with altitude, compensated by an increase of the sulfate fraction. This finding is consistent with previous airborne studies over Europe (Morgan et al., 2009) and over Wyoming (Pratt and Prather, 2010). Interestingly, $\mathrm{S}$ and $\mathrm{E}$ air masses show an enhancement of the total mass concentration (mainly organics) in the intermediate layer (1$3 \mathrm{~km}$ ), suggesting an efficient long-range transport of aerosol particles. These results are consistent with the transport of dust for the $\mathrm{S}$ air masses found in this layer by the simulated results (Begue et al., 2012). For the $\mathrm{E}$ air masses, the transport of pollutants (between 1 and $3 \mathrm{~km}$ ) may be the results of the dynamics change (difference in the boundary layer height and/or the residual layer effect) over the continent leading to a mixing between the lower layers and the free troposphere. 
In the LFT, the volume concentrations calculated by the SMPS are consistent with those given by the total mass concentration measured from the AMS. Indeed, the highest values of the mass concentration are associated with $\mathrm{E}$ air masses while the lowest are associated with NE air masses. Air masses from eastern Europe have been measured in both layers for both synoptic conditions, and the comparison as a function of the meteorology reveals different behaviour. During cyclonic conditions, the sulfate contribution increases significantly by a factor of 1.3 in the BL and a factor of 1.5 in the LFT. The cloud processing occurring during the cyclonic period may enhance the concentration of sulfate (Kerminen, 2001). As the other air mass sectors were not sampled in both conditions and in both layers, the impact of synoptic conditions on aerosol cannot be confirmed.

A clear signature can be seen for the chemical composition of particles originating from NE during anticyclonic conditions (HP). Indeed, unlike in the BL, the predominant chemical components of $90 \%$ of the measured mass concentration of non-refractory aerosol are sulfate and ammonium. The remaining $10 \%$ mass concentration measured by the AMS is composed mainly of nitrate and organics. During NE periods, the organic absolute concentrations are low $\left(<0.05 \mu \mathrm{g} \mathrm{m}^{-3}\right)$ as well as the total non-refractory aerosol concentration $\left(\sim 1 \mu \mathrm{g} \mathrm{m}^{-3}\right)$, which is comparable to results of a study on background rural aerosol particles (Hock et al., 2008). In situ measurements performed at Mace Head (O'Dowd et al., 2010) highlight that extended particle formation and growth events are not unusual over the Atlantic Ocean. Thus, the particular NE chemical composition might be linked to nucleation events occurring along the air mass transport.

\subsection{CCN properties}

To characterize the relationship between cloud condensation nuclei $(\mathrm{CCN})$ and corresponding aerosol populations (concentration of particles greater than $100 \mathrm{~nm}$ diameter), the $\mathrm{CCN} / N_{100}$ ratio can be introduced as a measure of hygroscopicity of the aerosol population. Indeed, since measurements made with both CPCs include numerous ultra-fine particles which are not likely to act as $\mathrm{CCN}$, the total aerosol concentration cannot be used as a reference for the aerosol concentration available for the activation process. Taking into account an average value of $100 \mathrm{~nm}$ as the minimum activation diameter for aerosol particles (Asmi et al., 2012; Wilcox et al., 2006), SMPS measurements were used to provide the $N_{100}$ concentrations required to calculate CCN / $N_{100}$ ratios. The CCN / $N_{100}$ ratio as a function of air mass groups sampled during EUCAARI is shown in Fig. 7. As these ratios are highly dependent on the aerosol concentrations, the $\mathrm{CCN}$ number concentrations were plotted (black points) for all air mass groups. During the anticyclonic conditions (HP), no $\mathrm{CCN}$ data were acquired in the NE sector air masses.
In the $\mathrm{BL}$, the $\mathrm{CCN}$ concentrations range from very low values $\left(<70 \mathrm{~cm}^{-3}\right.$, for $\mathrm{NW}$ sector $)$ to high values $\left(1570 \mathrm{~cm}^{-3}\right.$ for W sector). The values of the CCN $/ N_{100}$ ratios (0.17-0.34) are similar for all air mass groups for both cyclonic (LP) and anticyclonic (HP) conditions except the $\mathrm{NW}$ sector, which is associated with the lowest $\mathrm{CCN} / N_{100}$ ratio. Despite this slight difference, the $\mathrm{CCN} / N_{100}$ ratio is rather constant (around 0.25), which is consistent with the same chemical composition of particles. The measurement variability, i.e. $120 \%$, is similar for all air mass groups (except NW, in which it is higher) likely because of very low $\mathrm{CCN}$ and $N_{100}$ concentrations.

The CCN concentrations $\left(65-420 \mathrm{~cm}^{-3}\right)$ observed in the LFT are 3 times lower than the values observed in the BL, but the CCN / $N_{100}$ ratio is higher $(0.38-0.6)$. One can note that, in the BL as well as in the LFT, the highest CCN concentrations are measured for the most polluted sectors (E and $\mathrm{S}$, Fig. 7) while the highest $\mathrm{CCN} / N_{100}$ ratio values are measured for polar air masses in the LFT. Using the aerosol number concentrations described in Table 2, the $N_{100} / N_{10}$ ratio is calculated for each air mass origin and is found higher within the BL than within the LFT for the same regimes (LP/HP) except for the clean air masses (NE and P). The presence of larger particles in the BL should lead to an enhancement of the CCN/ $N_{100}$ ratio in the BL except for the clean air masses. However, the $\mathrm{CCN} / N_{100}$ ratio is higher in the LFT than in the BL likely due to the higher fraction of sulfate in the LFT.

\subsection{Optical properties}

Figure 8 presents the ratio of the total scattering coefficient to the number concentration of optically active particles with diameter larger than $150 \mathrm{~nm}$ (derived from the number size distributions). This normalized ratio corresponds to the average scattering efficiency of one optically active particle, i.e. the particle scattering cross section. The same analysis has been performed using the surface of optically active particles $\left(S_{150}\right)$, leading to similar results. A few measurements with very low values of the scattering coefficient $\left(<5 \mathrm{Mm}^{-1}\right)$, mainly found for two different air mass sectors (NE and NW), have been removed, since the scattering cross section cannot be derived with high confidence for these data. During anticyclonic conditions (HP), only observations from E are therefore presented in both layers. The average scattering cross section of a particle is about $0.026 \mu \mathrm{m}^{-2}$ in the BL and $0.052 \mu \mathrm{m}^{-2}$ in the LFT. Thus, particles sampled in the LFT scatter light 2 times more efficiently than particles sampled in the BL during anticyclonic conditions.

During cyclonic situations, the average scattering cross section is found lower than $0.064 \mu \mathrm{m}^{-2}$ in the BL. The maximum value is associated with polar air masses, while minimum values (about $0.032 \mu \mathrm{m}^{-2}$ ) are calculated for air masses from NE and $\mathrm{E}$ sectors. It is interesting to note that aerosol particles from the more (E) and the less (NE) polluted air 

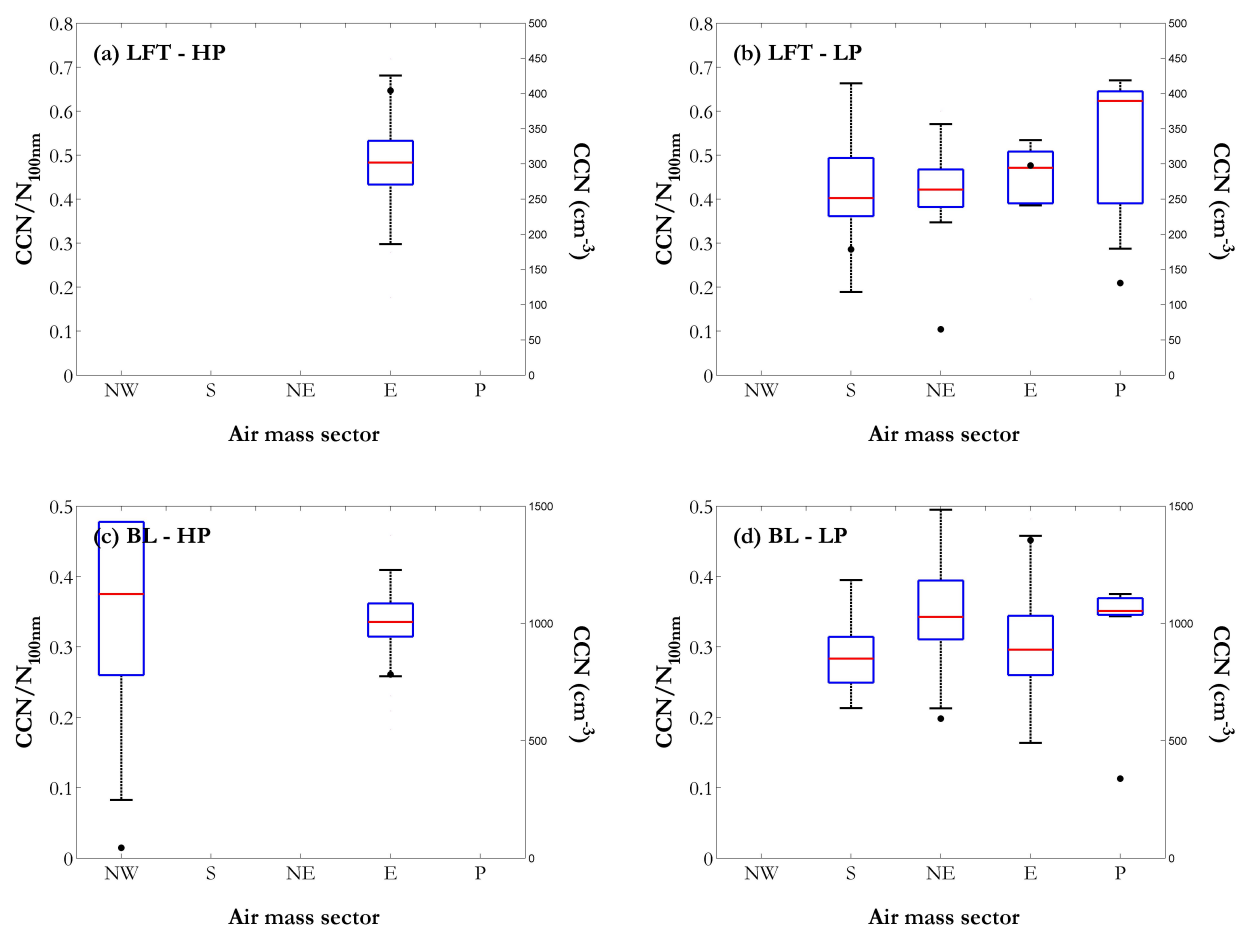

Fig. 7. CCN / $N_{100}$ ratios as a function of the air mass origin (NW: north-west Europe; S: south Europe; NE: north Europe; E: east Europe; P: Polar) in the lower free troposphere during anticyclonic (HP, a) and cyclonic (LP, b) conditions as well as in the boundary layer during anticyclonic (HP, c) and cyclonic (LP, d) conditions. Black points represent the median CCN concentration (right scale). Lower and upper limits of the box correspond to $25 \%$ and $75 \%$ percentiles, bottom and top whiskers the $5 \%$ and $95 \%$. Middle red bars indicate the median $\mathrm{CCN} / \mathrm{N} 100$ values.

masses have the same scattering efficiency. In the lower free troposphere, the average values of the scattering cross section are larger than $0.04 \mu \mathrm{m}^{-2}$, but the general trend, according to the different air masses, is totally opposite of the one observed in the boundary layer. Indeed, the average scattering cross section of aerosol particles from polar air masses is the weakest $\left(0.048 \mu \mathrm{m}^{-2}\right)$, while for polluted air masses (E and $S$ ) values are higher (around $0.13 \mu \mathrm{m}^{-2}$ ). When comparing values observed in the BL and in the LFT during cyclonic conditions, one can conclude that the scattering cross sections of particles are 4 times higher in the LFT than in the $\mathrm{BL}$ for the polluted air masses $(\mathrm{E}, \mathrm{W})$, while they are 1.33 times higher in the BL than in the LFT for polar air masses. Due to the similarities between the scattering cross section as a function of number and surface concentration $\left(N_{150}\right.$ and $\left.S_{150}\right)$, these considerable differences between both layers are then a consequence of different chemical composition. Indeed, the presence of aerosol particles in the LFT is connected to long residence time leading to the modification of the aerosol chemical composition due to the presence of more or less complete coating on the aerosol particle surface (Falkovich et al., 2004; Zhang et al., 2005; Ekman et al., 2006; Roger et al., 2009; Matsuki et al., 2010b). In contrast, aerosol particles in the BL had less time to be altered after their emission from the source (Doran et al., 2007).

\section{Summary}

This study compiles for the first time coincident observations over Europe (during the EUCAARI project) of the aerosol physical, chemical, optical and hygroscopic properties performed on board the ATR-42 in the boundary layer (BL) as well as in the lower free troposphere (LFT). The obtained measurements document clear relations between aerosol properties and air mass origins based on backward calculations with a Lagrangian particle dispersion model (FLEXPART).

The observations reveal enhanced mass concentrations of aerosol particles in the boundary layer (average between 10 and $30 \mu \mathrm{g} \mathrm{m}^{-3}$ ) and generally less in the lower free troposphere (average between 0.8 and $14 \mu \mathrm{g} \mathrm{m}^{-3}$ ). These mass concentrations are significantly higher than observed during previous airborne studies, for example over England (Morgan et al., 2009; BL $<20 \mu \mathrm{g} \mathrm{m}^{-3}$ and LFT $<5 \mu \mathrm{g} \mathrm{m}^{-3}$ ) and in particular over London (McMeeking et al., 2012; $\mathrm{BL}<12 \mu \mathrm{g} \mathrm{m}^{-3}$ and LFT $<8 \mu \mathrm{g} \mathrm{m}^{-3}$ ) during the same season (late spring, early summer). The high aerosol mass 

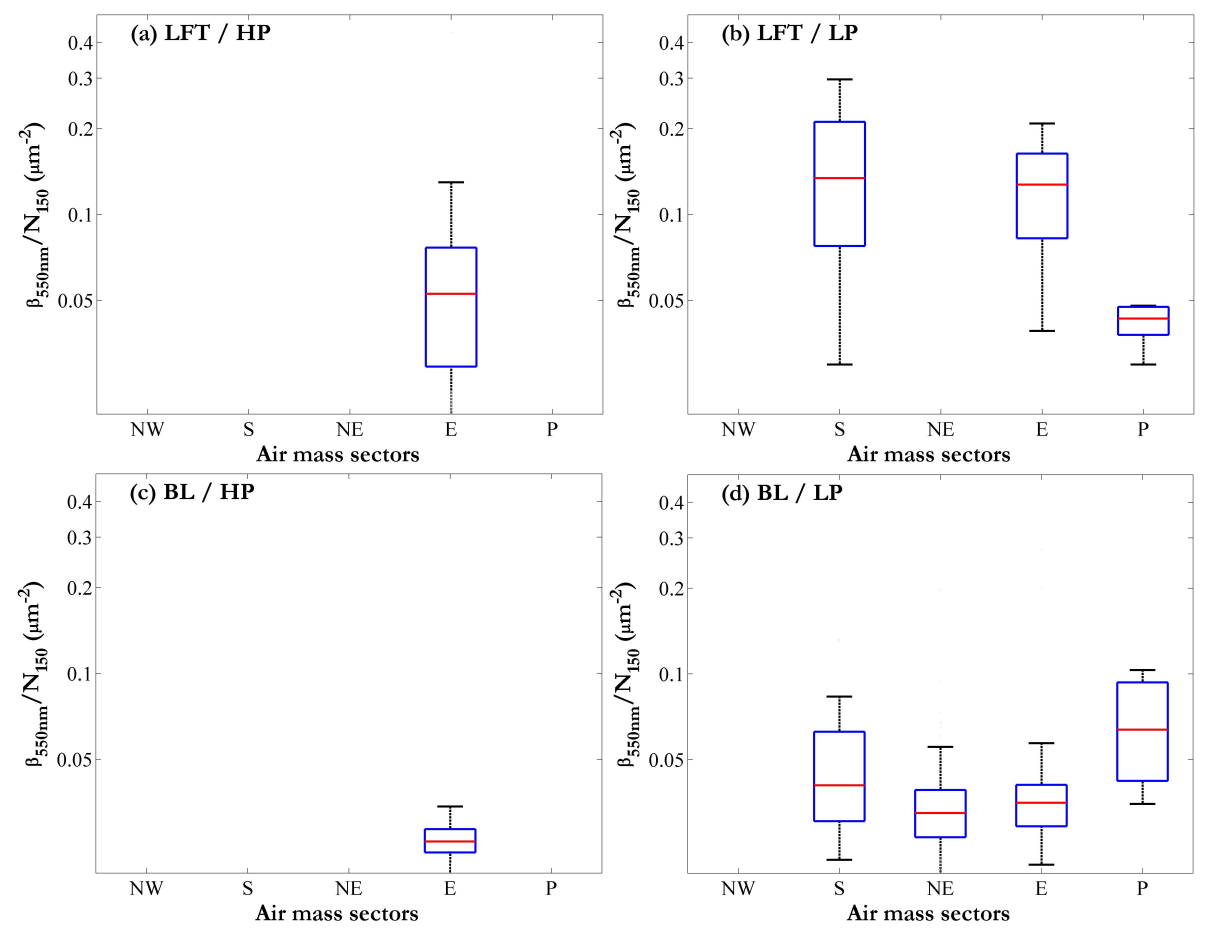

Fig. 8. Scattering cross section calculated at $550 \mathrm{~nm}$ wavelength for particles larger than $150 \mathrm{~nm}$ as a function of the air mass origin (NW: north-west Europe; S: south Europe; NE: north Europe; E: east Europe; P: polar) in the lower free troposphere (LFT) during anticyclonic (HP, a) and cyclonic (LP, b) conditions as well as in the boundary layer (BL) during anticyclonic (HP, c) and cyclonic (LP, d) conditions. Lower and upper limits of the box correspond to $25 \%$ and $75 \%$ percentiles, bottom and top whiskers the $5 \%$ and $95 \%$. Middle bars indicate the median.

concentrations in our study are mainly induced by the high mass contribution of organics that are 5 times larger in our study as compared to the above-cited observations.

Polluted air masses, coming from east and south Europe, are characterized by high total number particle concentrations and low concentrations of ultra-fine particles $\left(N_{10-50}\right)$. The relative chemical composition of particles within polluted air masses is dominated by organics (about 50\%) and nitrates (20\%) with notable amounts of sulfate. Non-polluted air masses, in general originating from polar $(\mathrm{P})$ and Scandinavian (NE) regions, are characterized by high total particle concentrations most likely related to preceding new particle formation events. Interestingly, the chemical composition of aerosol particles coming from Scandinavian regions (NE) are mainly $(\sim 80 \%)$ composed of ammonium sulfate. The observation of that type of chemical composition as well as the presence of relatively small particles (smaller than $100 \mathrm{~nm}$ ) is rather unique in the unpolluted lower free troposphere and is comparable with the properties of nucleation particles several hours (0-12 h) after their formation (Jung et al., 2006). These particles are most likely linked with nucleation events that have been shown to occur over the North Sea (O'Dowd et al., 2010).

Overall, the scattering cross-section profiles show a positive gradient with altitude. These gradients are stronger in the case of polluted air masses by a factor of two compared to the non-polluted air masses. Moreover, the hygroscopic properties $\left(\mathrm{CCN} / N_{100}\right)$ of the aerosols are similar for all air masses within each layer (BL and LFT) and are larger in the LFT compared to the BL due to higher sulfate fraction.

The large data set collected during the EUCAARI campaign and presented in this study may be of interest for the mesoscale chemical transport model community, for validation of chemical aerosol sources and formation of secondary organic aerosols (SOA) at high altitudes. The coupling of the aerosol physico-chemical properties with their direct and indirect effects can be further tested within the same data set.

\section{Supplementary material related to this article is available online at: http://www.atmos-chem-phys.net/13/ 4877/2013/acp-13-4877-2013-supplement.pdf.}

Acknowledgements. This work has been partially funded by European Commission 6th Framework programme project EUCAARI, contract no. 036833-2 (EUCAARI), and by the French National Research Agency (ANR) under the AEROCLOUD programme, contract no. 06-BLAN-0209. Suzanne Crumeyrolle has been supported by a CNRS fellowship (contract no. 167641). The 
authors wish to thank the SAFIRE (Service des Avions Français Instruments pour la Recherche en Environnement) for preparing and delivering the research aircraft (ATR-42). The authors want to thank the anonymous reviewers as well as the Editor for their advice and helpful comments to this work.

Edited by: A. Wiedensohler

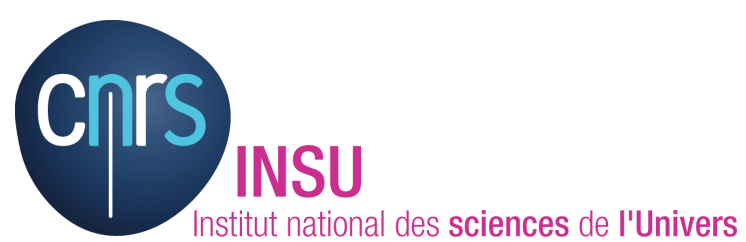

The publication of this article is financed by CNRS-INSU.

\section{References}

Adams, P. J. and Seinfeld, J. H.: Predicting global aerosol size distributions in general 3 circulation models, J. Geophys. Res., 107, 4370, doi:10.1029/2001JD001010, 2002.

Allan, J. D., Jimenez, J. L., Williams, P. I., Alfarra, M. R., Bower, K. N., Jayne, J. T., Coe, H., and Worsnop, D. R.: Quantitative sampling using an Aerodyne aerosol mass spectrometer $\hat{a}^{“} 1$. Techniques of data interpretation and error analysis, J. Geophys. Res.-Atmos., 108, 4090, doi:10.1029/2002JD002358, 2003.

Andreae, M. O. and Crutzen, P. J.: Atmospheric Aerosols: Biogeochemical sources and role in atmospheric chemistry, Science, 276, 1052-1058, 1997.

Asmi, A., Wiedensohler, A., Laj, P., Fjaeraa, A.-M., Sellegri, K., Birmili, W., Weingartner, E., Baltensperger, U., Zdimal, V., Zikova, N., Putaud, J.-P., Marinoni, A., Tunved, P., Hansson, H.C., Fiebig, M., Kivekäs, N., Lihavainen, H., Asmi, E., Ulevicius, V., Aalto, P. P., Swietlicki, E., Kristensson, A., Mihalopoulos, N., Kalivitis, N., Kalapov, I., Kiss, G., de Leeuw, G., Henzing, B., Harrison, R. M., Beddows, D., O’Dowd, C., Jennings, S. G., Flentje, H., Weinhold, K., Meinhardt, F., Ries, L., and Kulmala, M.: Number size distributions and seasonality of submicron particles in Europe 2008-2009, Atmos. Chem. Phys., 11, 5505-5538, doi:10.5194/acp-11-5505-2011, 2011.

Asmi, E., Freney, E., Hervo, M., Picard, D., Rose, C., Colomb, A., and Sellegri, K.: Aerosol cloud activation in summer and winter at puy-de-Dôme high altitude site in France, Atmos. Chem. Phys., 12, 11589-11607, doi:10.5194/acp-12-11589-2012, 2012.

Baron, P. A. and Willeke, K.: Aerosol Measurement, 2nd ed., John Wiley, Hoboken, NJ, 2001.

Bègue, P., Tulet, P., Chaboureau, J.-P., Roberts, G., Gomes, L., and Mallet, M.: Long-range transport of Saharan dust over northwestern Europe during EUCAARI 2008 campaign: Evolution of dust optical properties by scavenging, J. Geophys. Res., 117, D17201, doi:10.1029/2012JD017611, 2012.

Birmili, W., Wiedensohler, A., Heintzenberg, J., and Lehmann, K.: Atmospheric particle number size distribution in Central Europe: Statistical relations to air masses and meteorology, J. Geophys. Res., 106, 32005-32018, 2001.

Bond, T. C., Habib, G., and Bergstrom, R. W.: Limitations in the enhancement of visible light absorption due to mixing state, J. Geo- phys. Res.-Atmos., 111, D20211, doi:10.1029/2006jd007315, 2006.

Canagaratna, M. R., Jayne, J. T., Jimenez, J. L., Allan, J. D., Alfarra, M. R., Zhang, Q., Onasch, T. B., Drewnick, F., Coe, H., Middlebrook, A., Delia, A., Williams, L. R., Trimborn, A. M., Northway, M. J., DeCarlo, P. F., Kolb, C. E., Davidovits, P., and Worsnop, D. R.: Chemical and Microphysical Characterization of Ambient Aerosols with the Aerodyne Aerosol Mass Spectrometer, Mass Spectrom. Rev., 26, 185-222, 2007.

Crosier, J., Allan, J. D., Coe, H., Bower, K. N., Formenti, P., and Williams, P. I.: Chemical composition of summertime aerosol in the Po Valley (Italy), northern Adriatic and Black Sea, Q. J. R. Meteorol. Soc., 133, 61-75, doi:10.1002/qj.88, 2007.

Crumeyrolle, S., Manninen, H. E., Sellegri, K., Roberts, G., Gomes, L., Kulmala, M., Weigel, R., Laj, P., and Schwarzenboeck, A.: New particle formation events measured on board the ATR-42 aircraft during the EUCAARI campaign, Atmos. Chem. Phys., 10, 6721-6735, doi:10.5194/acp-10-6721-2010, 2010.

Crumeyrolle, S., Weigel, R., Sellegri, K., Roberts, G., Gomes, L., Stohl, A., Laj, P., Bourianne, T., Etcheberry, J. M., Villani, P., Pichon, J. M., and Schwarzenboeck, A.: Impact of cloud processes on aerosol particle properties: results from two ATR-42 flights in an extended stratocumulus cloud layer during the EUCAARI campaign (2008), Atmos. Chem. Phys. Discuss., 11, 33229-33271, doi:10.5194/acpd-11-33229-2011, 2011.

DeCarlo, P. F., Dunlea, E. J., Kimmel, J. R., Aiken, A. C., Sueper, D., Crounse, J., Wennberg, P. O., Emmons, L., Shinozuka, Y., Clarke, A., Zhou, J., Tomlinson, J., Collins, D. R., Knapp, D., Weinheimer, A. J., Montzka, D. D., Campos, T., and Jimenez, J. L.: Fast airborne aerosol size and chemistry measurements above Mexico City and Central Mexico during the MILAGRO campaign, Atmos. Chem. Phys., 8, 4027-4048, doi:10.5194/acp-84027-2008, 2008.

Doran, J. C., Barnard, J. C., Arnott, W. P., Cary, R., Coulter, R., Fast, J. D., Kassianov, E. I., Kleinman, L., Laulainen, N. S., Martin, T., Paredes-Miranda, G., Pekour, M. S., Shaw, W. J., Smith, D. F., Springston, S. R., and Yu, X.-Y.: The T1-T2 study: evolution of aerosol properties downwind of Mexico City, Atmos. Chem. Phys., 7, 1585-1598, doi:10.5194/acp-7-1585-2007, 2007.

Drewnick, F., Hings, S. S., DeCarlo, P. F., Jayne, J. T., Gonin, M., Fuhrer, K., Weimer, S., Jimenez, J. L., Demerjian, K. L., Borrmann, S., and Worsnop, D. R.: A new Time-of-Flight Aerosol Mass Spectrometer (ToF-AMS) - Instrument Description and First Field Deployment, Aerosol Sci. Technol., 39, 637-658, 2005.

ECMWF: User Guide to ECMWF Products 2.1, Meteorol. Bull. M3.2, ECMWF, Reading, UK, 1995.

Ekman, A. M. L., Wang, C., Wilson, J., Ström, J., and Krejci, R.: Explicit Simulation of Aerosol Physics in a Cloud-Resolving Model: Aerosol Transport and Processing in the Free Troposphere, J. Atmos. Sci., 63, 682-696, 2006.

Emanuel, K. A. and Zivkovic-Rothman, M.: Development and evaluation of a convection scheme for use in climate models, J. Atmos. Sci., 56, 1766-1782, 1999.

Falkovich, A. H., Ganor, E., Levin, Z., Formenti, P., and Rudich, Y.: Chemical and mineralogical analysis of individual mineral dust particles, J. Geophys. Res., 106, 18029-18036, doi:10.1029/2000JD900430, 2001. 
Falkovich, A. H., Schkolnik, G., Ganor, E., and Rudich, Y.: Adsorption of organic compounds pertinent to urban environments onto mineral dust particles, J. Geophys. Res.-Atmos., 109, D01201, doi:01210.01029/02003JD003919, 2004.

Hamburger, T., McMeeking, G., Minikin, A., Birmili, W., Dall'Osto, M., O’Dowd, C., Flentje, H., Henzing, B., Junninen, H., Kristensson, A., de Leeuw, G., Stohl, A., Burkhart, J. F., Coe, H., Krejci, R., and Petzold, A.: Overview of the synoptic and pollution situation over Europe during the EUCAARILONGREX field campaign, Atmos. Chem. Phys., 11, 10651082, doi:10.5194/acp-11-1065-2011, 2011.

Haywood, J., Francis, P., Osborne, S., Glew, M., Loeb, N., Highwood, E., Tanre, D., Myhre, G., Formenti, P., and Hirst, E.: Radiative properties and direct radiative effect of Saharan dust measured by the C-130 aircraft during SHADE: 1 . Solar spectrum, J. Geophys. Res., 108, 8577, doi:10.1029/2002JD002687, 2003.

Hock, N., Schneider, J., Borrmann, S., Römpp, A., Moortgat, G., Franze, T., Schauer, C., Pöschl, U., Plass-Dülmer, C., and Berresheim, H.: Rural continental aerosol properties and processes observed during the Hohenpeissenberg Aerosol Characterization Experiment (HAZE2002), Atmos. Chem. Phys., 8, 603-623, doi:10.5194/acp-8-603-2008, 2008.

IPCC: Intergovernmental Panel on Climate Change. Climate Change 2007 The Physical Science Basis: Contribution of Working Group I to the Fourth Assessment Report of the IPCC, Cambridge: Cambridge University Press, 2007.

Jeong, C.-H., McGuire, M. L., Godri, K. J., Slowik, J. G., Rehbein, P. J. G., and Evans, G. J.: Quantification of aerosol chemical composition using continuous single particle measurements, Atmos. Chem. Phys., 11, 7027-7044, doi:10.5194/acp-11-70272011, 2011.

Jokinen, V. and Mäkelä, J.: Closed loop arrangement with critical orifice for DMA sheath/excess fl ow system, J.Aerosol Sci., 28, 643-648, 1996.

Jung, J., Adams, P. J., and Pandis, S. N.: Simulating the size distribution and chemical composition of ultrafine particles during nucleation events, Atmos. Environ., 40, 2248-2259, 2006.

Katrib, Y., Martin, S. T., Rudich, Y., Davidovits, P., Jayne, J. T., and Worsnop, D. R.: Density changes of aerosol particles as a result of chemical reaction, Atmos. Chem. Phys., 5, 275-291, doi:10.5194/acp-5-275-2005, 2005.

Kaufman, Y. J., Tanre, D., and Boucher, O.: A satellite view of aerosols in the climate system, Nature, 419, 215-223, 2002.

Kerminen, V.-M.: Relative roles of secondary sulfate and organics in atmospheric cloud condensation nuclei production, J. Geophys. Res., 106, 17321-17333, doi:10.1029/2001JD900204, 2001.

Kinne, S., Schulz, M., Textor, C., Guibert, S., Balkanski, Y., Bauer, S. E., Berntsen, T., Berglen, T. F., Boucher, O., Chin, M., Collins, W., Dentener, F., Diehl, T., Easter, R., Feichter, J., Fillmore, D., Ghan, S., Ginoux, P., Gong, S., Grini, A., Hendricks, J., Herzog, M., Horowitz, L., Isaksen, I., Iversen, T., Kirkevåg, A., Kloster, S., Koch, D., Kristjansson, J. E., Krol, M., Lauer, A., Lamarque, J. F., Lesins, G., Liu, X., Lohmann, U., Montanaro, V., Myhre, G., Penner, J., Pitari, G., Reddy, S., Seland, O., Stier, P., Takemura, T., and Tie, X.: An AeroCom initial assessment - optical properties in aerosol component modules of global models, Atmos. Chem. Phys., 6, 1815-1834, doi:10.5194/acp-6-1815-2006, 2006.
Kulmala, M., Asmi, A., Lappalainen, H. K., Carslaw, K. S., Pöschl, U., Baltensperger, U., Hov, Ø., Brenquier, J.-L., Pandis, S. N., Facchini, M. C., Hansson, H.-C., Wiedensohler, A., and O'Dowd, C. D.: Introduction: European Integrated Project on Aerosol Cloud Climate and Air Quality interactions (EUCAARI) - integrating aerosol research from nano to global scales, Atmos. Chem. Phys., 9, 2825-2841, doi:10.5194/acp-9-2825-2009, 2009.

Lanz, V. A., Alfarra, M. R., Baltensperger, U., Buchmann, B., Hueglin, C., and Prévôt, A. S. H.: Source apportionment of submicron organic aerosols at an urban site by factor analytical modelling of aerosol mass spectra, Atmos. Chem. Phys., 7, 15031522, doi:10.5194/acp-7-1503-2007, 2007.

Lohmann U., Broekhuizen, K., Leaitch, R., Shantz, N., and Abbatt, J.: How efficient is cloud droplet formation of organic aerosols?, Geophys. Res. Lett., 31, L05108, doi:10.1029/2003GL018999, 2004.

Matsuki, A., Quennehen, B., Schwarzenboeck, A., Crumeyrolle, S., Venzac, H., Laj, P., and Gomes, L.: Temporal and vertical variations of aerosol physical and chemical properties over West Africa: AMMA aircraft campaign in summer 2006, Atmos. Chem. Phys., 10, 8437-8451, doi:10.5194/acp-10-84372010, 2010a.

Matsuki, A., Schwarzenboeck, A., Venzac, H., Laj, P., Crumeyrolle, S., and Gomes, L.: Cloud processing of mineral dust: direct comparison of cloud residual and clear sky particles during AMMA aircraft campaign in summer 2006, Atmos. Chem. Phys., 10, 1057-1069, doi:10.5194/acp-10-1057-2010, 2010 b.

McMeeking, G. R., Bart, M., Chazette, P., Haywood, J. M., Hopkins, J. R., McQuaid, J. B., Morgan, W. T., Raut, J.-C., Ryder, C. L., Savage, N., Turnbull, K., and Coe, H.: Airborne measurements of trace gases and aerosols over the London metropolitan region, Atmos. Chem. Phys., 12, 5163-5187, doi:10.5194/acp12-5163-2012, 2012.

McMurry, P. H.: The History of CPCs, Aerosol Sci. Technol., 33, 297-322, 2000.

McNaughton, C. S., Clarke, A. D., Howell, S. G., Pinkerton, M., Anderson, B., THornhill, L., Hudgins, C., Winstead, E., Dibb, J. E., Sceuer, E., and Maring, H.: Results from the DC-8 Inlet Characterization Experiment (DICE): Airborne Versus Surface Sampling of Mineral Dust and Sea Salt Aerosols, Aerosol Sci. Technol., 41, 136-159, 2007.

Mertes, S., Schrooder, F., and Wiedensohler, A.: The particle detection efficiency curve of the TSI3010 CPC as a function of temperature difference between saturator and condenser, Aerosol Sci. Technol., 23, 257-270, 1995.

Mirme, S., Mirme, A., Minikin, A., Petzold, A., Hõrrak, U., Kerminen, V.-M., and Kulmala, M.: Atmospheric sub-3 nm particles at high altitudes, Atmos. Chem. Phys., 10, 437-451, doi:10.5194/acp-10-437-2010, 2010.

Morgan, W. T., Allan, J. D., Bower, K. N., Capes, G., Crosier, J., Williams, P. I., and Coe, H.: Vertical distribution of sub-micron aerosol chemical composition from North-Western Europe and the North-East Atlantic, Atmos. Chem. Phys., 9, 5389-5401, doi:10.5194/acp-9-5389-2009, 2009.

Morgan, W. T., Allan, J. D., Bower, K. N., Esselborn, M., Harris, B., Henzing, J. S., Highwood, E. J., Kiendler-Scharr, A., McMeeking, G. R., Mensah, A. A., Northway, M. J., Osborne, S., Williams, P. I., Krejci, R., and Coe, H.: Enhancement of the 
aerosol direct radiative effect by semi-volatile aerosol components: airborne measurements in North-Western Europe, Atmos. Chem. Phys. Discuss., 10, 10653-10705, doi:10.5194/acpd-1010653-2010, 2010.

O'Dowd, C., Monahan, C., and Dall'Osto, M.: On the occurrence of open ocean particle production and growth events, Geophys. Res. Lett., 37, L19805, doi:10.1029/2010GL044679, 2010.

Petzold, A., Fiebig, M., Flentje, H., Keil, A., Leiterer, U., Schröder, F., Stifter, A., Wendisch, M., and Wendling, P.: Vertical variability of aerosol properties observed at a continental site during LACE 98, J. Geophys. Res., 107, LAC 10-1-LAC 10-18, doi:10.1029/2001JD001043, 2002.

Putaud, J.-P., Raes, F., Van Dingenen, R., Bruggemann, E., Facchini, M. C., Decesari, S., Fuzzi, S., Gehrig, R., Huglin, C., Laj, P., Lorbeer, G., Maenhaut, W., Mihalopoulos, N., Muller, K., Querol, X., Rodriguez, S., Schneider, J., Spindler, G., Ten Brink, H., Torseth, K., and Wiedensohler, A.:A European aerosol phenomenology - 2: chemical characteristics of particulate matter at kerbside, urban, rural and background sites in Europe, Atmos. Environ., 38, 2579-2595, 2004.

Prather, K. A.: Aircraft measurements of vertical profiles of aerosol mixing states, J. Geophys. Res.-Atmos., 115, D11305, 2010.

Quennehen, B., Schwarzenboeck, A., Schmale, J., Schneider, J., Sodemann, H., Stohl, A., Ancellet, G., Crumeyrolle, S., and Law, K. S.: Physical and chemical properties of pollution aerosol particles transported from North America to Greenland as measured during the POLARCAT summer campaign, Atmos. Chem. Phys., 11, 10947-10963, doi:10.5194/acp-11-10947-2011, 2011.

Raes, F., van Dingenen, R., Vignati, E., Wilson, J., Putaud, J.-P., Seinfeld, J. H., and Adams, P.: Formation and cycling of aerosols in the global troposphere, Atmos. Environ., 34, 4215-4240, 2000.

Roberts, G. C. and Nenes, A.: A Continuous-Flow Streamwise Thermal-Gradient CCN Chamber for Atmospheric Measurements, Aerosol Sci. Technol., 39, 206-221, 2005.

Roberts, G. C., Andreae, M. O., Zhou, J., and Artaxo, P.: Cloud condensation nuclei in the Amazon Basin: Marine conditions over a continent?, Geophys. Res. Lett., 28, 2807-2810, 2001.

Roger, J. C., Guinot, B., Cachier, H., Mallet, M., Dubovik, O., and Yu, T.: Aerosol complexity in megacities: From size resolved chemical composition to optical properties of the Beijing atmospheric particles, Geophys. Res. Lett., 36, L18806, doi:10.1029/2009GL039238, 2009.

Sagan, C. and Pollack, J. B.: Anisotropic nonconservative scattering and the clouds of Venus, J. Geophys. Res., 72, 469-477, 1967.

Schulz, M., Textor, C., Kinne, S., Balkanski, Y., Bauer, S., Berntsen, T., Berglen, T., Boucher, O., Dentener, F., Guibert, S., Isaksen, I. S. A., Iversen, T., Koch, D., Kirkevåg, A., Liu, X., Montanaro, V., Myhre, G., Penner, J. E., Pitari, G., Reddy, S., Seland, $\varnothing$. ., Stier, P., and Takemura, T.: Radiative forcing by aerosols as derived from the AeroCom present-day and pre-industrial simulations, Atmos. Chem. Phys., 6, 5225-5246, doi:10.5194/acp-65225-2006, 2006.

Slowik, J. G., Stainken, K., Davidovits, P., Williams, L. R., Jayne, J. T., Kolb, C. E., Worsnop, D. R., Rudich, Y., DeCarlo, P., and Jimenez, J. L.: Particle Morphology and Density Characterization by Combined Mobility and Aerodynamic Diameter Measurements. Part 2: Application to combustion Generated Soot Aerosols as a Function of Fuel Equivalence Ratio, Aerosol Sci. Technol., 38, 1206-1222, 2004.
Slowik, J. G., Cross, E. S., Han, J., Davidovits, P., Onasch, T. B., Jayne, J. T., Williams, L. R., Canagaratna, M. R., Worsnop, D. R., Chakrabarty, R. K., Moosmüller, H., Arnott, W. P., Schwarz, J. P., Gao, R., Fahey, D. W., Kok, G. L., and Petzold, A.: An InterComparison of Instruments Measuring Black Carbon Content of Soot Particles, Aerosol Sci. Technol., 41, 295-314, 2007.

Spichtinger P. and Cziczo, D. J.: Aerosol-cloud interactions a challenge for measurements and modeling at the cutting edge of cloud climate interactions, Environ. Res. Lett., 3, 025002, doi:10.1088/1748-9326/3/2/025002, 2008.

Stohl A. and Thomson, D. J.: A density correction for Lagrangian particle dispersion models, Boundary Lay. Meteorol., 90, 155167, 1999.

Stohl, A., Hittenberger, M., and Wotawa, G.: Validation of the Lagrangian particle dispersion model FLEXPART against large scale tracer experiment data, Atmos. Environ., 24, 4245-4264, 1998.

Stohl, A., Forster, C., Frank, A., Seibert, P., and Wotawa, G.: Technical note: The Lagrangian particle dispersion model FLEXPART version 6.2, Atmos. Chem. Phys., 5, 2461-2474, doi:10.5194/acp-5-2461-2005, 2005.

Stoltzenburg, M. R. and McMurry, P. H.: An ultrafine aerosol condensation nucleus counter, Aerosol Sci. Technol., 14, 48-65, 1991.

Textor, C., Schulz, M., Guibert, S., Kinne, S., Balkanski, Y., Bauer, S., Berntsen, T., Berglen, T., Boucher, O., Chin, M., Dentener, F., Diehl, T., Easter, R., Feichter, H., Fillmore, D., Ghan, S., Ginoux, P., Gong, S., Grini, A., Hendricks, J., Horowitz, L., Huang, P., Isaksen, I., Iversen, I., Kloster, S., Koch, D., Kirkevåg, A., Kristjansson, J. E., Krol, M., Lauer, A., Lamarque, J. F., Liu, X., Montanaro, V., Myhre, G., Penner, J., Pitari, G., Reddy, S., Seland, Ø., Stier, P., Takemura, T., and Tie, X.: Analysis and quantification of the diversities of aerosol life cycles within AeroCom, Atmos. Chem. Phys., 6, 1777-1813, doi:10.5194/acp-6-1777-2006, 2006.

Tunved, P., Nilsson, E. D., Hansson, H.-C., Ström, J., Kulmala, M., Aalto, P., and Viisanen, Y.: Aerosol characteristics of air masses in northern Europe: Influences of location, transport, sinks, and sources, J. Geophys. Res., 110, D07201, doi:10.1029/2004JD005085, 2005.

Van Dingenen, R., Putaud, J.-P., Martins-Dos Santos, S., and Raes, F.: Physical aerosol properties and their relation to air mass origin at Monte Cimone (Italy) during the first MINATROC campaign, Atmos. Chem. Phys., 5, 2203-2226, doi:10.5194/acp-52203-2005, 2005.

Villani, P., Picard, D., Marchand, N., and Laj, P.: Design and Validation of a Volatility Tandem Differential Mobility Analyzer (VTDMA), Aerosol Sci. Technol., 41, 898-906, 2007.

Volkamer, R., Jimenez, J. L., San Martini, F., Dzepina, K., Zhang, Q., Salcedo, D., Molina, L. T., Worsnop, D. R., and Molina, M. J.: Secondary organic aerosol formation from anthropogenic air pollution: rapid and higher than expected, Geophys. Res. Lett., 33, L17811, doi:10.1029/2006GL026899, 2006.

von der Weiden, S.-L., Drewnick, F., and Borrmann, S.: Particle Loss Calculator - a new software tool for the assessment of the performance of aerosol inlet systems, Atmos. Meas. Tech., 2, 479-494, doi:10.5194/amt-2-479-2009, 2009.

Wang, M., Ghan, S., Easter, R., Ovchinnikov, M., Liu, X., Kassianov, E., Qian, Y., Gustafson Jr., W. I., Larson, V. E., Schanen, 
D. P., Khairoutdinov, M., and Morrison, H.: The multi-scale aerosol-climate model PNNL-MMF: model description and evaluation, Geosci. Model Dev., 4, 137-168, doi:10.5194/gmd-4137-2011, 2011.

Wiedensohler, A., Birmili, W., Nowak, A., Sonntag, A., Weinhold, K., Merkel, M., Wehner, B., Tuch, T., Pfeifer, S., Fiebig, M., Fjäraa, A. M., Asmi, E., Sellegri, K., Depuy, R., Venzac, H., Villani, P., Laj, P., Aalto, P., Ogren, J. A., Swietlicki, E., Williams, P., Roldin, P., Quincey, P., Hüglin, C., Fierz-Schmidhauser, R., Gysel, M., Weingartner, E., Riccobono, F., Santos, S., Grüning, C., Faloon, K., Beddows, D., Harrison, R., Monahan, C., Jennings, S. G., O'Dowd, C. D., Marinoni, A., Horn, H.-G., Keck, L., Jiang, J., Scheckman, J., McMurry, P. H., Deng, Z., Zhao, C. S., Moerman, M., Henzing, B., de Leeuw, G., Löschau, G., and Bastian, S.: Mobility particle size spectrometers: harmonization of technical standards and data structure to facilitate high quality long-term observations of atmospheric particle number size distributions, Atmos. Meas. Tech., 5, 657-685, doi:10.5194/amt5-657-2012, 2012.

Wilcox, E. M., Roberts, G., and Ramanathan, V.: Influence of aerosols on the shortwave cloud radiative forcing from north Pacific Oceanic Clouds: Results from the Cloud Indirect Forcing Experiment (CIFEX), Geophys. Res. Lett., 33, L21804, doi:10.1029/2006GL027150, 2006.
Williams, J., de Reus, M., Krejci, R., Fischer, H., and Ström, J.: Application of the variability-size relationship to atmospheric aerosol studies: estimating aerosol lifetimes and ages, Atmos. Chem. Phys., 2, 133-145, doi:10.5194/acp-2-133-2002, 2002.

Zhang, Q., Jimenez, J. L., Canagaratna, M. R., Allan, J. D., Coe, H., Ulbrich, I., Alfarra, M. R., Takami, A., Middlebrook, A. M., Sun, Y. L., Dzepina, K., Dunlea, E. J., Docherty, K. S., Decarlo, P. F., Salcedo, D., Onasch, T., Jayne, J. T., Miyoshi, T., Shimono, A., Hatakeyama, S., Takegawa, N., Kondo, Y., Schneider, J., Drewnick, F., Borrmann, S., Weimer, S., Demerjian, K. L., Williams, P., Bower, K. N., Bahreini, R., Cottrell, L., Griffin, R. J., Rautiainen, J., Sun, J. Y., Zhang, Y. M., and Worsnop, D. R.: Ubiquity and dominance of oxygenated species in organic aerosols in anthropogenically-influenced Northern Hemisphere midlatitudes, Geophys. Res. Lett., 34, L13801, doi:10.1029/2007GL029979, 2007.

Zorn, S. R., Drewnick, F., Schott, M., Hoffmann, T., and Borrmann, S.: Characterization of the South Atlantic marine boundary layer aerosol using an aerodyne aerosol mass spectrometer, Atmos. Chem. Phys., 8, 4711-4728, doi:10.5194/acp-8-47112008, 2008. 